\title{
Ritual, Self and Yoga: On the Ways and Goals of Salvation in the Kațha Upanișad
}

\author{
Dominik $\operatorname{Haas}^{1}$ (D)
}

Published online: 5 August 2019

(C) The Author(s) 2019

\begin{abstract}
Throughout its history, the renowned Kațha Upanișad has often been described as being both incoherent and contradictory. The aim of this paper is to show to what purpose the text was created. To this end, it discusses the connection of the three paths to salvation depicted in the text, viz. the Agnicayana (a powerful Vedic fire-ritual), the Upanișadic method of self-knowledge, and yoga. The first part retraces how in the Upanișads, the Agnicayana was transformed into a non-material or mental ritual and linked with self-knowledge. The second part analyses how the various salvation goals (heaven, the World of Brahman, liberation from rebirth) could be related to each other. First, the authors redefined the Agnicayana's salvation goal, heaven, to make it identical with liberation. Secondly, they introduced self-knowledge and yoga as alternative and equally powerful means to the same end. In practice, however, the new and world-negating methods were implied to be superior to the costly ritual from which they had drawn their authority. Thus, the authors of the Upanișad were more concerned with showing continuity between different religious approaches than upholding consistency of content.
\end{abstract}

Keywords Agnicayana $\cdot$ Self $\cdot$ Yoga $\cdot$ Immortality $\cdot$ Heaven $\cdot$ Liberation

Dominik Haas

dominik.haas@univie.ac.at

1 University of Vienna, Vienna, Austria 


\section{Introduction ${ }^{1}$}

What remains of human beings when they die? Does existence continue after death or not? In the Katha Upanișad (KU), a curious Brahmin boy named Naciketas addresses this question to Death himself. Previously, Death—also referred to as Yama—proved to be a bad host by neglecting to serve his Brahmin guest for three nights; in recompense, he is now obliged to grant Naciketas three boons, or wishes. Naciketas seizes upon this opportunity, asking his host first to see his father, who out of anger had sent him to Death in the first place, in a happy mood again. For his second boon, he requests a ritual which effectuates an immortal state after death and is even renamed by Yama as Nāciketacayana. Lastly, Naciketas questions him about the existence of human beings after death.

The question of how Naciketas's wishes and Death's answers should be understood has given rise to various contradictory interpretations from both traditional commentators and modern scholars. The KU has often been translated, commented upon and interpreted. ${ }^{2}$ Like many other Upanișads, it contains elements from various religious epochs, currents and milieus. Its beginning consists of a story about the attainment of a fire-ritual (the Nāciketacayana, a sub-form of the Agnicayana) leading to a heavenly immortality, which has been adapted from the middle-Vedic Taittirīya Brāhmana (TB) to suit the needs of the text. ${ }^{3}$ The bulk of the text is dedicated to answering the question of whether or not a human being does exist after death, and consists of an anthology of verses on the immortal soul or self (variously called purusa and atman). Here, it is no longer a fire-ritual, but a kind of gnostic practice or meditation technique (probably called yoga for the very first time) which liberates the practitioner from the cycle of reincarnation. Now a question arises: if the soul or self is already immortal, why then would one need a fire-ritual, self-knowledge or yoga in order to attain immortality? And further: why would one need three different methods?

Even a cursory reading shows that several hands were involved in the creation of the text. It is practically undisputed that the verses of the KU have different origins and were not composed by one single author. As a largely compiled text, the KU is a perfect example of adaptive reuse, a longstanding phenomenon often found in architecture, which has recently received special attention in South Asian Studies. ${ }^{4}$

\footnotetext{
${ }^{1}$ I would like to thank Vitus Angermeier, Kenji Takahashi, Christèle Barois and the anonymous reviewer for their valuable suggestions on a previous version of this paper. I also thank Sarah Kiehne for reading the English manuscript and suggesting various corrections and Thomas Kintaert for his help in translating passages from Faddegon's Dutch paper. Translations of German and Sanskrit texts are my own, unless otherwise stated.

${ }^{2}$ Important contributions addressing the interpretation of the KU have been made (among others) by Müller (1884, pp. xxi-xxv, 1-24), Böhtlingk (1890, 1891), Whitney (1890), Deussen (1894, pp. 175178), Deussen (1921, pp. 261-287), Faddegon (1923), Charpentier (1928/29), Rawson (1934), Johnston (1939), Weller (1953), Helfer (1968), Velankar (1968), Wadhwani (1973), Lipner (1978), Bodewitz (1985), DeVries (1987), Oberlies (1988), Grinshpon (2003, pp. 80-100), Cohen (2008, pp. 193-212), Smith (2016) and Norelius (2017). For emendations of the text, see especially Hillebrandt (1914), Alsdorf (1950), Friš (1955) and (for further and older literature) Weller (1953).

3 TB III 11.8.1-6. Translations can be found in Müller (1884, pp. xxi-xxii), Deussen (1921, pp. 262263), Whitney (1890, pp. 89-90), and Dumont (1951, pp. 652-653) (including an edition).

${ }^{4}$ See in particular the collected papers in Freschi and Maas (2017) and Freschi (2015). Reuse can be called adaptive when an already existing, identifiable object-a building or, in the literary context, a (piece of) text-is adapted and reused by another author for his own purposes, which deviate from the
} 
The framework narrative of the Upanișad is exemplary here: the beginning of the Naciketas story is quoted verbatim from the TB, but is then continued with new textual material in order to adapt the story to the purpose of the text. ${ }^{5}$

As the Naciketas story from the TB at the beginning of the text illustrates, adaptive reuse has been part of the concept of the KU since the very start. Now, while so-called interpolations certainly exist in the KU-obviously, those who transmitted the text also took over the spirit in which it was created-it is much more interesting to see how generations of teachers and students could make sense of the text at all. ${ }^{6}$ Even if in South Asia textual material was often retained only out of respect for tradition, the fact that the Brahmin frame story not only persisted but was even augmented by (possibly later) insertions and referred back to in the other Vallīs strongly suggests that it was not unimportant for later redactors. Assuming that they did not accumulate verses indiscriminately, one can reasonably ask what sense they saw in linking such a mosaic of spiritual aphorisms with a story about a Vedic fire-ritual.

The aim of this paper is to show to what purpose the text was created and how the KU may have been understood by its first recipients. In order to provide the background for this new interpretation, it discusses the connection of the three paths to salvation mentioned in the text, viz. the Agnicayana (a powerful Vedic fire-ritual), the Upanișadic method of selfknowledge, and yoga. In the section "The Agnicayana and the Self," I will retrace how the Agnicayana developed in other Upanișads, where it was adapted as a mentally or verbally performed ritual and linked with self-knowledge. In the section "Heaven, Liberation and the World of Brahman," I will carve out the similarities of the salvation goals of the various methods taught in the KU.

My basic assumption is that the authors of the Upanișad were concerned more with showing continuity between different religious approaches than upholding consistency of content. First, they redefined the Agnicayana's salvation goal, heaven, to be identical with liberation. Secondly, they introduced self-knowledge and yoga as alternative and equally powerful means to the same end. In practice, however, the new and world-negating methods were implied to be superior to the costly ritual from which they had drawn their authority.

Before offering a new interpretation of the $\mathrm{KU}-$ one which is based on a more constructive reading of the text-I want to summarize briefly how the text has been interpreted over the last two centuries up until the recent past. This will show how my interpretation can serve as a counterweight to the approaches of previous scholarship, which still prove to be influential outside the small world of modern Sanskrit philology.

Footnote 4 continued

original; e. g., if a castle is used as a museum; see Freschi and Maas (2017, p. 13). Ibd. it is also stated that the original use must have been interrupted.

5 In addition to the framework narrative, most of the other verses, too, were probably already in existence before the creation of the KU. However, since their original context is unknown, it remains open as to what extent they are mere reuses or cases of adaptive reuse in the actual sense. Most often it is only possible to interpret the verses or verse groups of the text in their new context-no straightforward task, as demonstrated by the amount of literature written on the KU.

6 The earliest commentary on the KU is Śankara's, who probably lived about a millennium after the creation of the KU. Since this paper focuses on the early history of the KU, his interpretation (as well as the interpretations of his successors) will not be considered. 


\section{The Ritualists and the Philosophers}

For most scholars, the Vedic ritual, which is explained to Naciketas as his second boon, could not be reconciled with the gnostic teachings and yoga practices which constitute the greater part of the text. According to the "traditional" explanation of European and American academia, the KU is an anti-ritualistic document. Its present shape is the product of a row of redactors who inflated the text with ever more additions and interpolations. In doing so, however, they ignored the inevitable inconsistencies and contradictions which emerged over time. Consequently, much scholarship has been devoted to the restoration of a more coherent text by determining which passages are original and which are later interpolations. This was often guided by a kind of intuition about the coherence or frictions between the different parts of the text-an approach which does not generally facilitate objective verification.

The greatest advocate of this method was Friedrich Weller, for whom 'the KU reflects how, in the course of time, different convictions contended with each other. ${ }^{7}$ For him, the KU is like a protocol which records the corrective measures taken by 'sacrificial technicians' ("Opfertechniker") who were opposed to the new Upanișadic wisdom and the yoga teachings presented in the text. Weller interpreted the passages about the Nāciketacayana-which by that time had not yet been identified as such - as an effort made by the guardians of the ritualistic religion to defend their raison d'être as mediators of salvation.

The anti-ritualistic reading followed by Weller was most pointedly propounded by William Dwight Whitney and later elaborated by Paul Deussen. ${ }^{8}$ Deussen believed the version of the Naciketas story found in the TB to be based on that of the $\mathrm{KU} .{ }^{9} \mathrm{He}$ considered this version to be the original because he reckoned the doublemention of the ritual in the TB to be a remodelling of sacrificial priests. ${ }^{10}$ For him,

\footnotetext{
7 Tr. of Weller (1953, p. 21): "als habe sich in der Kațhopanișad niedergeschlagen, wie die verschiedenen Überzeugungen im Laufe der Zeit miteinander rangen."

${ }^{8}$ Cf. Whitney (1890, p. 91): "It is, indeed, little less than absurd that the boy extorts from Death the disclosure of a ceremonial rite that renders one immortal in heaven, and then follows it up with an inquiry whether there is another world and another life." Others tended to follow the more constructive approach of the traditional commentators, who often divide the Upanișad into a karmakāṇda (a 'ritual section') and a jñannakānda (a 'knowledge section'), the former being devoted to heaven and the latter to final release (mukti). In this case, Naciketas's question is understood to exclusively concern the state of the released man (mukta); cf. Geldner (1901, p. 154), n. 1; Charpentier (1928, p. 225, n. 103).

9 Apart from Deussen, apparently only James S. Helfer favored the idea that the KU reflects an earlier version of the story: "The version found in the Taittirīya Brāhmana is 'archaic' only in the sense that it is earlier. It is quite possible, and even highly probable, that the version found in the Kathopanisad reflects a more archaic version because it is obviously more complete and reveals much more detail of the esoteric rite." Helfer (1968, p. 353, n. 19).

${ }^{10}$ Cf. Deussen (1894, pp. 176-177): "[O]ffenbar muss ursprünglich in den drei Wünschen [des TB] eine Steigerung gelegen haben. Der erste bezieht sich auf irdisches Wohlergehen. Der zweite auf die Vergeltung der guten Werke nach dem Tode; ist sie erfolgt, ist der Schatz der guten Werke verbraucht, so muss die Seele zu einem neuen Leben und neuen Sterben auf die Erde zurückkehren [...] Nun folgt der dritte Wunsch, welcher, mit der jenseitigen Vergeltung und Wiederkehr zum Erdendasein nicht zufrieden, nach dem Mittel fragt, das Wiedersterben abzuwehren. Dieses Mittel aber kann nicht wiederum das Naciketas-Feuer sein, eben weil es das Mittel zu dem zweiten Zwecke war, - ganz abgesehen von der Sinnlosigkeit, die darin liegt, nochmals zu lehren, was eben erst gelehrt worden - es muss also wohl hier schon in der ursprünglichen Erzählung die Lehre von der ewigen Erlösung im Sinne der Upanishad's
} 
there must have originally been an increase in the three boons of the TB: the first refers to this-worldly well-being, the second concerns the retribution of the good works after death and the third asks for the means to ward off repeated death. Since in the TB the means to the latter two goals is the Nāciketacayana, for Deussen the third boon originally must have concerned eternal salvation (as in the KU) and was only later clumsily replaced by a ritualist who considered the doctrine of salvation as unsuitable to his purposes.

Deussen's assumption that there is a contradiction between the result of the ritual and eternal salvation even forced him to dismiss the literal meaning of the text. As his second boon, Naciketas asks for the Agni that leads to heaven. Since neither death nor old age exist in this eternal realm, the conclusion must be drawn that any person being there is immortal. ${ }^{11}$ Deussen, however, did not follow this logic and claimed that the result of the ritual is by no means eternal. In his translation of the $\mathrm{KU}$, he elliptically comments that the fire-ritual only leads to temporary heavenly bliss, even though this is not explicitly stated in the 'enthusiastic description' of the text. ${ }^{12}$ The third wish, on the other hand, is not directed to the knowledge of survival after death, which is presupposed as established in the second wish, but at the knowledge of the self and the eternal salvation which ensues from this knowledge. ${ }^{13}$

Weller's analysis, too, is based on the assumption that there exists a stark contradiction between the path of cognition and that of the sacrificial cult. For him, the KU was originally created to defend the necessity of sacrificial priests, who feared their own superfluity should immortality become achievable without the need for their mediation. ${ }^{14}$ To counter this threat, they simply inserted text passages that again emphasize the importance of the ritual.

This method of explaining the text inevitably raises objections. To assume that the text owes its present shape to the fact that its creators and preservers were blinded by their own ignorance and selfishness is bold at best. Even if the KU, over

\section{Footnote 10 continued}

gestanden haben, welche jedoch von dem Verfasser des Taitt. Br. als zu seinen Zwecken nicht passend beseitigt und (plump genug) durch die nochmalige Erwähnung des Naciketas-Feuers ersetzt wurde."

$11 \mathrm{KU}$ 1.12-13, 17 and 18. For an analysis of the salvation goal of the KU, see below, "Salvation in the Kața Upanișad". Surprisingly, the possibility that the KU really means what it says was at first tentatively (!) remarked by E. H. Johnston $(1939$, p. 126, n. 1) in a footnote: "I would observe that [the $\mathrm{KU}]$ takes, so far as I know, the archaic view that the second stage, heaven, is a permanent state, where amrtatva is enjoyed (i. 13)."

12 Cf. Deussen (1921, p. 268): "Der zweite Wunsch, die vorübergehende [!] (vgl. [KU] 2,10) himmlische Seligkeit betreffend. Daß dieselbe nur vorübergehend sei, wird bei ihrer enthusiastischen Schilderung im folgenden nicht streng festgehalten. Das Mittel zu ihr ist die Schichtung des Nâciketa-Feuers, welche hier den Opferkultus im allgemeinen zu repräsentieren scheint."

13 Cf. Deussen (1921, p. 270): "Der dritte Wunsch, nicht sowohl (wie es nach der Fragestellung, Vers [KU 2.]20 scheinen kann) auf das Wissen von dem Fortleben nach dem Tode,-denn dieses wird ja schon in der vorhergehenden Frage als feststehend vorausgesetzt,--sondern vielmehr auf die Erkenntnis des Âtman als der wahren Wesenheit des Menschen und damit auf die ewige Erlösung gerichtet."

14 Cf. Weller (1953, p. 20): "Erringt jemand wie die Unsterblichkeit aus sich heraus, ohne der entscheidenden Leistung eines Mittlers zu bedürfen, dann verliert der Opferpriester seinen Lebensquell, weil er überflüssig wird, wenn er kein Opfer mehr zu vollziehen hat, anderen die Türe zur himmlischen Welt zu öffnen. [...] Das führte in unserer dazu, daß die gefährdeten Opferpriester dem Neuen, das sie bedrohte, das Alte in zähem Beharren wieder entgegenstellten." 
its history, may have cross cut different milieus, Weller does not explain why the transmitters of the KU would make a text worse by keeping roughly three quarters of its unwanted "spiritual" or anti-ritualistic content (instead of just burying it in oblivion). Obviously, Weller's approach would require a far more elaborate clarification of the relationship between ritual, self-knowledge, yoga and its proponents. To simply dismiss the ritual as a poorly revived religious remnant raises more questions than it answers. ${ }^{15}$

However, the opposite direction of interpretation also presents certain pitfalls. Recently, Caley Charles Smith presented a distinctly ritualistic reading of the text. $\mathrm{He}$ interprets the first Vallī of the KU as a kind of "reversed representation" of several ritual acts of the Agnicayana. He assigns the following ritual acts to the narrative sections of the $\mathrm{KU}$ :

1. Naciketas threatens Death as or like a Vaiśvānara fire (KU 1.7). In the ritual, this corresponds to the transport of the fire from the new Gārhapatya fireplace (the former Āhavanīya) to the fire-altar (Agni). ${ }^{16}$ Naciketas thus represents the fire: "While the precise ritual details are not clear, the passage seems to depict fire on the altar as a guest."17

2. Naciketas, the unserved and therefore dangerous Brahmin/fire, must be appeased. In the ritual, this corresponds to appeasing the altar with recitations and/or water: "KathU 1.7 likens fire to a guest thirsty for water, but the pacification of this thirst, śantim kurvanti, may refer to the ritual pacification of the fire as well."18 The theme of appeasement also continues with the angry father, although he is not associated with any fire.

3. The Srnikā, the golden necklace obtained, has a ritual parallel in the Agnicayana. ${ }^{19}$

According to Smith, the reverse sequence of these events-the transport of the fire and the threat it poses, its appeasement and the integration of the Srnikā into the layers of the altar-explains the metaphysical basis of the Agnicayana. ${ }^{20}$ In this way, the KU "explains why a proper Black Yajurvedic agnicayana can transport sacrificers to heaven.", 1

While some allusions and references cited by Smith could well be understood by a connoisseur of the ritual (which undoubtedly plays an important role), there are certain reasons that speak against this interpretation. First, it is based on the nonobjective selection of some elements from both the ritual acts and the sequences: not

\footnotetext{
15 A devastating judgment on Weller's theories was also passed by Bodewitz (1985, pp. 6-10), who discusses the above-mentioned points of criticism in more detail. He concludes (p. 10): "Weller's sketch of the rivalry between the ritualists and the philosophers ([Weller 1953,] p. 20) [...] is pure fiction."

16 Smith (2016, p. 287, n. 20), however, notes that this transport may not have been part of the Nāciketacayana.

17 Smith (2016, p. 287).

18 Smith (2016, p. 288).

19 Smith (2016, p. 289).

20 Smith (2016, p. 291).

21 Smith (2016, p. 293).
} 
only does the ritual contain many more sub-procedures than those mentioned by Smith, but also the KU revolves around much more content than the ritual which, strictly speaking, only represents the content of Naciketas's second wish. Furthermore, for Smith's analysis it is necessary to extract some pieces from the generally coherent flow of the narrative, abstract their content by fading out the context, and then read them in reverse order, fading out the overall context of the Upanișad.

In order to present a new interpretation of the KU, I suggest returning to the ritual and its interpretations as they can be found in the texts. The important studies of Henk W. Bodewitz (1985), Oberlies (1988/95/96/98), Toshifumi Gotō (1996) and Per-Johan Norelius (2017) have proven that this is, indeed, the most promising approach.

\section{The Agnicayana and the Self}

As his second boon, Naciketas asks for 'the Agni leading to heaven' (svargya agni), which means that he wants to learn the ritual which is performed using a fire-altar and results in the attainment of heaven. For a long time, both traditional commentators and modern scholars were unaware that the so-called nāciketa agni is actually part of a real, identifiable and meaningful ritual.

As the above makes clear, the primary reason for this was that the ritual was usually a priori discarded as a meaningful component of the narrative of the KU: neither the traditional Vedāntins nor the European and American researchers of the 19 th and 20th centuries wanted to deal with the philosophically uninteresting ritual in more detail, since for both types of recipients this represented an inferior or undeveloped form of religion.

Bodewitz was the first to follow the traces of the Nāciketacayana in the Brāhmanas in his seminal essay on the second boon of Naciketas (1985) and was able to solve some puzzles of this passage of the KU by considering the ritual literature. The ritual taught by Death is the so-called Nāciketacayana, the 'laying related to (or named after) Naciketas,' which in turn is one of the five variants of the famous Agnicayana. Since these variants, which originated in the school of the Kathas, ${ }^{22}$ presuppose the principles and basic structures of the Agnicayana, in the following I will quickly deal with the purposes and interpretations of this ritual before discussing its significance in other Upanișads and, most importantly, the $\mathrm{KU}^{23}$

The Brāhmanas mention several results of the Agnicayana, and there are numerous, partly diverging statements regarding the interpretation of the ritual acts. Interpretations of larger parts and of the entire ritual can be found in the Satapatha

\footnotetext{
22 See Dumont (1951, p. 630).

23 Descriptions of the ritual can be found, among others, in Weber (1873), summarized by Hillebrandt (1897, pp. 162-165); cf. also Dumont (1951, p. 629) and White (1986, p. 192, n. 14). Mention must of course also be made of the two volumes edited by Staal (1983), which primarily deal with a performance of the ritual in 1975 but also contain a general introduction (pp. 27-166).
} 
Brāhmaṇa (ŚB) in the Kāṇḍas VI-X, which feature Śāṇdilya as their leading teacher.

Most prominent is the central myth of Prajāpati and his son, Agni. In this myth, Prajāpati begins to dissolve after he has created the world, and Agni procures a new body for him. Modeled on this myth, the patron of the sacrifice, too, is to be made immortal by the fire-altar, which is aptly named Agni. Just like Agni reassembled a body for the dying Prajāpati on the cosmic or divine plane, so the priests construct a new divine self for the patron of the sacrifice or yajamāna on the ritual plane by means of the (usually bird-shaped) altar. In this manner, the yajamāna gains immortality after death with the new body created in ritual.

How this peculiar method works is illustrated in a story in the 10th Kānda of the ŚB (called agnirahasya, the 'Secret of/about Agni') where it is reported how the gods obtained the knowledge about the fire-altar. Their teacher, as in the KU and $\mathrm{TB}$, is Death. The result of the ritual is the overcoming of repeated death and immortality in the hereafter:

\section{ŚB X 4.3.10 ${ }^{24}$}

Those who know this (scil. the secret knowledge about the Agni) in this way or those who perform this ritual, come into existence again after death and, as soon as they come into existence (again), attain immortality. Those, however, who do not know in this way and those who do not perform this ritual, come into existence again after death and become food for precisely this one (scil. for death) again and again.

The desired effect of the ritual is based (among other things) on the ritual identification of different entities. Different acts and objects of the ritual, as for instance the inflammation of a fire, a certain utensil or a metre used in a hymn are put into meaningful relation with entities of the world or of the body. The "mystic" correspondences are a varied but important component of the ritual, the purpose of which is not least to correlate the microcosm with actions in the macrocosm.

As is known, the Brāhmanas are brimming with identifications, and even the ŚB itself concludes that ultimately, the fire-altar is everything (ŚB X 5.4.14). This total identification, however, does not amount to meaningless tautology. Quite the opposite: the altar is the whole transient world, and thus its construction (somewhat paradoxically) leads to the overcoming of exactly this transience and the attainment of both worldly goods and an immortal state after death.

Turning now to the Nāciketacayana, the purposes of the Agnicayana known to us from the SB can also be found in a similar form in the TB, which places special emphasis on knowledge. If someone conducts the ritual and has the correct knowledge of its correspondences (yá evám véda), 'verily, the desire with which he sacrifices is fulfilled' ${ }^{25}$ and 'he becomes the possessor of (safe) places and solidly

\footnotetext{
${ }^{24}$ té yá evám etád vidúh | yé vaitát kárma kurváte mṛtvā́ púnah sámbhavanti té saṃbhávanta evàmrtatvám abhisámbhavanty átha yá evám ná vidúr yé vaitát kárma ná kurváte mṛtvā púnah sámbhavanti tá etásyaivā́nnam púnahpunar bhavanti $\mid$.

25 sám ha và́ asmai sá kámạ̣ padyate | yátkāmo yájate | TB III 11.7.2.
} 
established. ${ }^{26}$ Most importantly, there are also otherworldly results for the knowing sacrificer: he 'enters with the body (of the Nāciketacayana) into the heavenly world' ${ }^{27}$ and gains 'an infinite, boundless and imperishable world behind the sun, ${ }^{28}$ and 'as someone standing on a chariot looks back at the turning side parts (= wheels), so he looks back at day and night, and day and night do not reach his world.' $^{29}$

Thus, the soteriological goal of the Agnicayana as well as the Nāciketacayana is the attainment of the state of infinite immortality. For the Nāciketacayana it is explicitly stated that after death, one reaches a somewhat abstract world behind or above the sun, where one is not only relieved of the alternation of day and night, but in particular, of repeated death.

The cosmology upon which this idea is based is more clearly articulated in the oldest Upaniṣads than in the Brāhmaṇas and Saṃitās. The old Upaniṣads state that the earth, which is covered by the vault of the sky, is similar to a "prison": after cremation, people who are "destined to be reborn go up to the moon in the form of smoke or vapor; from there they return to earth as rain." 30 On earth, they enter the plants, which are then eaten by a man and are transferred through his seed into the womb of a woman, where they finally assume a new body. The sun, however, is the door through which one can see what lies outside this prison and its cycle of rebirth and redeath, namely, a world of light and immortality. Those who have the liberating knowledge are able to break the cycle and escape through the bright opening in the sky.

The salvation as it can be found in some Brāhmaṇas and old Upaniṣads, which is not (yet) called mukti, thus refers to an escape from the cosmos rather than to a liberation from an eternal cycle of rebirths. Although the two concepts seem to be very similar on a superficial level (and actually were combined in later times), they can nevertheless be clearly distinguished in their original formulations and are likely to have originated in two different cultural milieus. However, at some point the concept of a more abstract cycle of rebirths, which is commonly known as Samsāra, did come into contact with the late Vedic conception, and this contact may have prompted the integration of the goal of eternal, never-ending immortality into the Vedic religion.

As is widely known, being a god in heaven was (and is) viewed as a finite state in Buddhism and other "heterodox" traditions. Adherents of this view therefore criticized that it makes little sense to carry out an elaborate ritual if one is doomed to die again when one's "credit" is exhausted. The advocates of Vedic ritualism, however, reacted accordingly:

At the end of the Vedic period [...] we see that with the popularity of other circles, their claims on a different "life" after death and their criticism of the

\footnotetext{
26 āyátanavān bhavati | gácchati pratișțắm | TB III 11.7.2.

27 sáśarīra evá svargám lokám eti | TB III 11.7.3.

28 [a]nantám apārám akṣayyám lokám jayati | yáh párenādityám | TB III 11.7.4.

29 yáthā ráthe tísțhan pákșasī paryāvártamāne pratyápekșate | evám ahorātré pratyápekṣate nấsyāhorātré lokám āpnutah | TB III 11.7.4.

30 Olivelle (1998, p. 21).
} 
Vedic claims for unlimited happiness and immortality were definitely taken seriously. Life in heaven became more and more dissociated from corporeal enjoyments. Criticism of the Vedic claim on permanent immortality in heaven was countered by the doctrine of the overcoming of death in heaven (punarmrtyu). In this threatened position the closed front of Vedic ritualism broke down, and deliverance from death in heaven (i.e., Vedic immortality) now became claimed by a limited number of rituals (especially the Agnicayana). ${ }^{31}$

Following Johannes Bronkhorst's approach, this process could also be classified as part of a centuries-long reaction of Brahmanical culture to the religion and spirituality that was at that time prevalent in the east of what is today's northern India. It is known that the so-called Śramana traditions, to which Buddhism and Jainism belong, originated in this area and were widespread above all in Magadha and its periphery. These currents had many lay followers and for a long time enjoyed the particular protection of the kings of Magadha. ${ }^{32}$ They offered a fundamentally different concept to that of ritualistic Brahmanism. Both the political support they enjoyed and their alternative worldviews posed a certain threat and challenged a reaction on the part of the Brahmin ritual religion, the epicenter of which in terms of orthodoxy and orthopraxy lay in the so-called Āryāvarta in the western Gangetic plain. Even the Agnicayana has been suspected of originating from outside the Vedic sphere, inter alia because of its otherwordly and life-denying orientation. $^{33}$

Among others, the conviction that a certain kind of knowledge of the true nature of the self, which is envisioned as immortal and changeless and leads to liberation, can be attributed to what Bronkhorst has called "the spiritual culture of Greater Magadha." ${ }^{34}$ In the following, I want to show how in several Upanișads the tenet of the self has been integrated into the Vedic worldview by connecting it with the Agnicayana, before reverting to the role of this ritual in the KU. ${ }^{35}$ In doing so, I want to demonstrate that the Agnicayana not only came to be viewed as an antidote to repeated death, but in the course of time also became the point of departure in

\footnotetext{
${ }^{31}$ Bodewitz (2002, p. 221). A perfect example of a very similar product of contact is the story of Yayāti, where the idea of karmic retribution is grafted onto the naturalistic conception of rebirth as it can be found in the early Upanișads; see Mahābhārata I 81.1-82.2; cf. Hill (2001, pp. 6-11).

${ }^{32}$ Cf. Bronkhorst (2007, pp. 1-14).

${ }^{33}$ Cf. Converse (1974, p. 91): "The strong emphasis on death, as well as fecundity, in the primal divine being, Prajāpati, who represents the cosmic process, tends to produce or to reflect a particular religious attitude toward the world; the believer regards the world, if not as suffering and evil at least as ambiguous, as a condition from which he seeks to escape. The world, the human situation, bears a negative valuation, and religion is regarded as assisting man to extricate himself from it.".

${ }^{34}$ See Bronkhorst (2007, p. 28). Although Buddhism, too, had its provenance in this culture, it was rather skeptical about the existence of an individual and eternal self and later, non-Buddhist literature definitely portrays it as denying the self. Since the KU was definitely created after Buddhism began to hold sway, it is very probable that those who in Naciketas's question do not believe in the existence of man after death are, in fact, Buddhists. For reasons of space, however, this matter cannot be discussed here.

${ }^{35}$ For a more detailed discussion of the Agnicayana and especially its relation to the Puruṣa in the heart and the solar Purușa, see Norelius (2017, pp. 445-459), who also followed the trail laid by Bodewitz (1985) in other Upanișads.
} 
other Upanișadic teachings about the Ātman, the immortal self of man, and his relationship to life after death.

As will be seen, in these cases, Vedic (or rather: ritualistic) tenets and the tenets of the culture of Greater Magadha have often blurred to the point where they have become indistinguishable: ritual merges with meditation, the body of the fire-altar is identified with the eternal Ātman and the naturalistic cycle of rebirths fuses with the concept of Saṃāara.

\section{Śāṇ̣̣ilya's Doctrine in the Chāndogya Upaniṣad}

In the Chāndogya Upanișad (ChU III 14) we find a short passage that contains a teaching ascribed to a teacher named Sanndilya (this teaching was later called Sanndịlya-Vidyā in the commentarial literature). ${ }^{36}$ According to this doctrine, the Ātman, i.e. the 'inner core of being' within man, should be venerated (upa+ās) ${ }^{37}$ as 'the Whole' (sarvam) and Brahman respectively, in order to become Brahman after death. ${ }^{38}$ The salvific effect of the teaching is thus based on the realization of a correspondence $(\bar{A} \operatorname{tman}=$ Brahman $)$ which is typical of the Upanișads.

The doctrine of the ChU obviously refers to a passage of the SBB also attributed to Sanndịlya, which is found in the 10th Kāṇda. ${ }^{39}$ In the doctrine of Brāhmaṇa, too, we find mention of the Brahman, which here is to be understood as 'the True' (satyá), as well as of the Ātman, which should be envisioned as a golden person having the size of a grain. However, the word brahman mentioned in this context in the SB probably does not refer to the cosmos, but rather, following its older meaning, denotes an effective and salvific 'formulation,' which—if the "older" Śanḍilya of the ŚB can be interpreted in this way-effectuates a new existence after death for someone who has the right willpower and conviction. ${ }^{40}$ If one accepts Śanḍilya's doctrine about the self-i.e., his brahman or formulation-as true and is sufficiently convinced of it, one will become this self after death.

It is very likely that the teaching of the later ChU was deliberately attributed to Saṇ̃ilya, the teacher known from the ŚB, in order to transfer his authority to the new, but similar teaching. In the past, the two teachings were not considered different, both because of this attribution and their similarity. Toshifumi Gotō (1996), however, showed that 'the doctrine of the ŚB, which attaches new sense to a concrete ritual action of the Agnicayana by means of an additional inner ritual, was taken by the author of the ChU and transformed into a doctrine about Ātman and Brahman. ${ }^{41}$ The Ātman, which in the ritual is created with the help of the Brahman

\footnotetext{
36 Cf. Gotō (1996, p. 71, n. 1) and Norelius (2017, pp. 450-451).

37 "When a text states that someone venerates $\mathrm{X}$ as $\mathrm{Y}$, the meaning is that he recognizes the hidden connection or homology between the two." Olivelle (1998, p. 24).

38 Translations of the text can be found in Olivelle (1998, p. 209) and Gotō (1996, pp. 73-74).

39 ŚB X 6.3. An English translation of the text can be found in Norelius (2017, p. 450).

${ }^{40}$ Cf. Gotō (1996, pp. 75-77).

41 Tr. of Gotō (1996, pp. 83-84): “Aus den vorgelegten Betrachtungen dürfte klar hervorgehen, dass die im ŚB belegte Lehre, die mit zusätzlichem innerem Ritual einen neuen Sinn in eine konkrete Ritualhandlung des hineinlegt, vom Verfasser der ChU in die Hand genommen und in eine UpanișadLehre über Ātman und Brahman umgestaltet wurde".
} 
(= the right formulation) for heaven, is in the Upanișad interpreted as an already existing, inner core of being which is to be identified with Brahman (= the cosmos).

Even if Śandililya's 'secret teaching about the fire-altar' (agnirahasya) came into existence after the creation of the ritual and must not be understood to be its only legitimate explanation, it was nevertheless strongly associated with the ritual, its effectiveness and its purpose: both the Agnicayana as well as the doctrines of the two Sanndilyas that are related to the ritual aim at procuring a post-mortal existence for the yajamāna or the believer in Śandililya's doctrine, respectively, by creating or realizing the Âtman.

\section{The "Altar of Words" in the Taittirīya Upanișad}

In the second chapter of the Taittirìya Upanișad (TU), the so-called Brahma Vallī, there is a description of five 'bodies' or 'selves' (Ātmans), which resemble a matryoshka doll, one being inside the other and each again consisting of five parts. These five bodies emulate the bird-shaped altar, which also consists of five parts (the bird's head, trunk, two wings and tail) and is formed of five layers of bricks. ${ }^{42}$

According to Yitzhak Freedman, the recitation of the text probably functioned as a kind of verbal ${ }^{43}$ ritual, in which a teacher constructs a new body for his pupil through the use of words or, rather, "unveils" it. ${ }^{44}$ The purpose of the ritual is thussimilar to the original - to create a new body for life after death, or more precisely: to recognize this body or self with the help of the teachings of the Upanișad. ${ }^{45}$ How the text was used and how it was related to the "material" Agnicayana is difficult to determine:

It might have been a separate procedure intended to replace the original agnicayana entirely, or a complementary one, perhaps using the brick-made agni as a model to which the teacher points as he utters the crucial words. Another possibility is that the construction of the self happened over a long period of time, during which it was broken up into five occasions, each of which was devoted to the creation of one of the five layers of the verbal agni in the disciple's evolving ätman. ${ }^{46}$

\footnotetext{
42 See Freedman (2012) and Norelius (2017, pp. 451-452). The five bodies in the TU (II 2.2-5) are (1) the material body 'consisting of food' (annamaya), (2) the body 'consisting of vital functions' (prānamaya), (3) the body 'consisting of mind' (manomaya), (4) the body 'consisting of recognition' (vijñānamaya) and (5) the body 'consisting of bliss' (änandamaya).

43 The demonstrative pronouns in the text indicate that it is not an interiorization or purely mental transformation of the ritual: "It can be heard and observed as it happens-a teacher is speaking and gesturing to his disciple." Freedman (2012, p. 336).

44 Cf. Freedman (2012, p. 336): “[I]n TU2, we find the basis for a performance of the ritual of constructing a self in the form of agni 'verbalized,' in the sense that in it, verbal actions, or speech acts (the uttering of statements such as 'this is his head'), replace physical actions (laying down an earthen brick during the agnicayana). It is a verbalized agnicayana." Of course, it must not be forgotten that the text could have been used outside such a verbal ritual and that in the later exegetics of Vedānta, it was also received independently from its original function.

45 Cf. Freedman (2012, p. 327): "This is a description of the final journey, the journey beyond death, which leads to the bliss residing in the core of man."

46 Freedman (2012, pp. 336-337).
} 
To me, it is quite possible that the altar was "built" or explained within the body of another, with the priest or teacher pointing not at the sacrificial ground, but at his own limbs or the limbs of whoever is to be made immortal. After all, the departure of the practice is the purușa, the 'man.' The "practice" starts: 'Now, a man here is formed from the essence of food. This here is his head [...]. ${ }^{47}$ All the other selves within adapt to this outer appearance of a man.

What is clear is that whoever applies the method of the text 'obtains the highest' possible plane of existence and attains 'all objects of desire, along with the wise brahman. ${ }^{48}$ The innermost self he gains is made of bliss (anandamaya) which is many times greater than that enjoyed by even the most enviable of all human beings (TU II 8-9).

\section{The Altar/Yogin in the Śvetāśvatara Upaniṣad}

In the Śvetāśvatara Upanișad (ŚU), which according to Thomas Oberlies presents an attempt to amalgamate the two gods Rudra and Agni, we find a number of Vedic quotations which originally were employed in the Agnicayana. ${ }^{49}$ Oberlies points out that the yoga practice which is taught in the following verses may have been modeled on the structure of the fire-altar. ${ }^{50}$ For his meditation, the practitioner (who is not explicitly called a yogin in this text) is supposed to keep his body 'triple erect' (trirunnata, ŚU II 8). Originally, this word was used to describe a special kind of devayajana or 'sacrificial ground' but was later transferred onto the altar itself. In the SU, the yogin "constructs" himself like (or as) the Agni/altar of the ritual, the three parts being his knees, navel and mouth. ${ }^{51}$

If Oberlies's thesis is correct, the ŚU presents another example of how spiritual practices were connected with the Agnicayana by a comparison of the yogin with the fire-altar. The salvation goal of the ritual, however, has not been taken over. In the ŚU, the immediate goal of yoga is to make one's body yogāgnimaya, i.e., to cause it to 'have the same nature as Agni by means of yoga' or to 'be constituted of the yoga-fire/Agni, ${ }^{52}$ and thus to become identical with the one god Agni/Rudra. The purpose of the practice is not the attainment of any kind of loka (let alone svarga) but the fulfillment of all desires, the obtainment of sovereignty, Brahman, immortality, endless peace, infinity, freedom from illness, suffering, age, (re)birth, and death. In short: liberation from Samsāra (saṃsāramokșa, ŚU VI 16). ${ }^{53}$

\footnotetext{
47 sa vā eșa puruṣo 'nnarasamayah | tasyedam eva śirah | TU II 1.1.

48 brahmavid āpnoti param |; sarvān kāmān saha brahmaṇā vipaścitā| TU II 1.1. Since vipaścit is usually not attributed to inanimate objects, it is very probable that brahman here does not refer to a formulation, but to the cosmic Brahman. On the translation of this verse, cf. also Beall (1986).

49 ŚU II 1-13, see Oberlies (1988, pp. 55-57).

${ }^{50}$ Oberlies (1998, pp. 48-54).

51 For the three parts or layers of the altar, see below, "The adhyātmayoga of the Katha Upanișad".

52 “durch Yoga mit Agni eines Wesens geworden” Oberlies (1988, p. 52). Oberlies (1996, p. 133, n. 51) later preferred the simpler translation "bestehend aus Yoga-Feuer."

53 For the salvation goal of the ŚU, see I 11, II 12, III 1, 7, 10, 13, 21, IV 11, 14-17, 20, V 7, 9, 13, VI 10, $13,15,16,19,20$.
} 


\section{The Maitrāyaṇiya Upaniṣad and the 3+2 Layers of the Altar}

The Maitrāyaṇiya Upanișad (MaiU) contains a rather detailed interpretation or elaboration of the concepts of the Agnicayana, in which the Ātman plays an important role. ${ }^{54}$ At the beginning of the Upanișad we read:

MaiU I 1.1 $1^{55}$

The fire-laying of the ancient was a Brahman-ritual. Therefore the sacrificer, having laid these fires, must think upon the self. Verily, it must be realized that the ritual becomes truly full and complete in all respects.

Immediately afterwards ${ }^{56}$ it is explained that the self is of a double nature, having, like in the KU, a bodily and a solar manifestation:

MaiU VI $1^{57}$

Verily, he carries his self in two ways, this one here which is the vital breath and that one there which is the sun.

In yet another passage, we even can find a teaching which is very similar to the "verbal Agnicayana" in the TU. Here, the goal of the (mental?) ritual is explicitly said to be Brahman:

\section{MaiU VI $33^{58}$}

This Agni, made of five bricks (= brick layers?), verily is the year. [...] Having a head, two wings, a back and a tail, this Agni is like a man. The earth here is Prajāpati's first laying. [...] The interspace here is Prajāpati's second laying. This sky is Prajāpati's third laying. With the hands he makes an offering of the yajamana to the Knower of the Self. The Knower of the Self, having thrown him upward, proffers him to Brahman. There he becomes blissful, joyful.

\footnotetext{
54 According to van Buitenen (1962, p. 37), in the MaiU the symbolism of the Agnicayana is transferred to the Agnyādhāna. Bodewitz (1985, p. 11, n. 27) denies this: "Probably the Agnihotra, the Agnicayana and their interiorizations (partly in the form of a Prānāgnihotra, partly to be regarded as a mental and symbolic Agnicayana) are meant here." He argues that ci respectively cayana can refer not only to the "layers," but also to the "contemplation" of the fire. Which of the two rituals is really meant, is difficult to determine; in any case, the symbolism comes from the Agnicayana.

55 brahmayajño vā eșa yat pūrveșām cayanam| tasmād yajamānaś citvaitān agnīn ātmānam abhidhyāyet | sa pūrṇah khalu vā addhāvikalah sampadyate yajñah $\mid$. Whether in the MaiU the ritual is replaced by a mental ritual or not, is controversial; see Bodewitz (1985, p. 11, n. 27). The Upanișad does not comment on this. The interpretations of the sacrifice are in any case clearly in the foreground of the text; van Buitenen (1962, p. 37) explains: "brahmayajña is a rite which is more than the literal observance of its ritual detail, and is accomplished by the esoteric knowledge of the macrocosmic and microcosmic connections implied."

56 The passages translated here are, in van Buitenen's (1962) view, part of the original version of the MaiU; in this version, this section and the next (regardless of the numbering) follow directly one after the other.

57 dvidhā vā eșa ātmānam bibharti | ayam yaḥ prāṇo yaś cāsā ādityah |.

58 pañceștako vā eșo 'gnih samvvatsarah | [...] śirahpakșasīprșțthapucchavān eșo 'gnih purușavidhah / [...] seyam prajāpateh prathamā citih [...] | tad idam antarikșạn prajāpater dvitīyā citih / saișa dyauh prajāpates tṛtīyā citịh | karair yajamānasyātmavide 'vadānam karoti / athātmavid utkșipya brahmane prāyacchat $\mid$ tatrānandī modī bhavati $\mid$. Cf. the tr. by van Buitenen (1962, pp. 48-49). For emendations integrated into the transcription and a discussion, see van Buitenen (1962, pp. 29-33).
} 
Here, three layers of the altar correspond to the cosmos: (1) earth, (2) interspace, (3) sky. Then follow two new elements, the 'Knower of the Self' (ätmavid) and Brahman. They are not, however, designated as the 4th and 5th layers. Both van Buitenen (1962, pp. 31-33) and Norelius (2017, p. 452), comparing the MaiU with the TU, identify these layers as (4) the self 'consisting of consciousness' (vijñānamaya) and (5) the self 'consisting of bliss' (ānandamaya). ${ }^{59}$

However, the situation seems to be more complex, and the fact that the MaiU does not call the 'Knower of the Self' (ätmavid) the 4th, and Brahman the 5th layer deserves attention. It is very likely that the MaiU does not envision the altar as having five layers, but rather three with two additional items that are not, strictly speaking, part of the structure of the altar. ${ }^{60}$ In order to shed more light on this difficult situation, in the following I will quickly review how the layers of the Agni were conceived of in the ŚB and in other Upanișads.

In the ŚB, Celaka Śāṇ̣ilyāyana (a descendant of Śāṇḍilya) explains:

\section{ŚB X 4.5.3 ${ }^{61}$}

The three layers containing the naturally-perforated (pebbles) are these very worlds here [viz. earth, interspace and sky], the fourth (layer) is the sacrificer, and the fifth (layer) is all objects of desire.

On this, Julius Eggeling (1897, p. 364, n. 2) remarks that the three layers containing the naturally-perforated pebbles are the 1st, 3rd and 5th physical layers and that the 2nd and 4th layers (which are called the fourth and the fifth by Celaka) are the additional layers in between. While in this idiosyncratic but comprehensible way of counting the extra layers might indeed be part of the physical altar, this is not as conclusive in later texts.

Given that the correspondences of the three main layers in the MaiU remain unaltered, it would a priori make sense to locate the two extra layers between the main layers as proposed by Eggeling for the ŚB. However, neither the MaiU nor the other texts give any indication that this is the case: the SU and the MaiU mention only three layers, and while the TU does enumerate five, the last two are not located between the three main layers (or selves, in that case) but rather inside them.

While it is clear that the bodies in the TU are each within the other, the MaiU adopts a more outward-looking perspective. This is suggested by the words upa +sam+kram 'to step over, to merge' and antare 'within' in the TU and ut+kșip 'throw up' in the MaiU. Since the extra layers or selves in these two Upanișads are otherwise very similar and are both added as the last items in a linear sequence, their location in the MaiU (which does not actually call them layers) is to be assumed not within or between, but outside or maybe on top of the three main parts of the altar. But what, then, happened to the two intermediate layers?

The easiest way to explain this confusing situation is to assume that the texts are somewhat confused themselves. The conflict produced by the conception of a three-

\footnotetext{
59 Cf. above, "The 'Altar of Words' in the Taittirīya Upanișad."

${ }^{60}$ Cf. Oberlies (1988, p. 51, n. 69).

61 imá evá lokā́s tisráh svayamātṛnnávatyaś cítayo yájamānaś caturthì sárve kā́māh pañcam[ī ...] |.
} 
Table 1 The layers of the Agnicayana in the Upanișads

\begin{tabular}{lllll}
\hline Physical layers & ŚB (layers) & TU (selves) & MaiU (layers) & ŚU (yogin) \\
\hline- & 5.? all desires & 5. bliss & 5. Brahman & \\
- & 4.? sacrificer & 4. recognition & 4. Knower of the Self & \\
5 & 3. (sky) & 3. mind & 3. sky & 3. mouth \\
4 & 5.? all desires & & & 2. navel \\
3 & 2. (interspace) & 2. vital breath & 2. interspace & 1. knees \\
2 & 4.? sacrificer & & & 1. earth \\
1 & 1. (earth) & 1. food & &
\end{tabular}

layered altar, which was known to have five (physical) layers was resolved by ignoring the fact that the three most important layers are not on top of each other. The physical construction of the altar obviously became less important in its mental or verbal derivatives. The idea of a $3+2$ structure of the altar, however, persisted and was interpreted more freely (see Table 1). In the ŚU, the "altar" was envisioned as a tripartite structure from the outset.

Thus, the Knower of the Self (the 4th item in the MaiU) may be understood to be his "true" and separate self or purușa (and not the 2nd physical layer), and Brahman to be the sphere above the three-layered cosmos comprising the earth, interspace and the sunlit sky (and not the 4th physical layer). ${ }^{62}$ The fact that Brahman could thus be located "above" the sky perfectly fits the cosmology of the middle and late Vedic period as described above.

To analyse in detail the many similarities between the MaiU and the KU is, of course, beyond the scope of this paper. In the following, only one further common feature of the two texts shall be briefly addressed, namely the fact that, just like the $\mathrm{KU}$, the MaiU juxtaposes the terminologies of ritual and yoga.

At the beginning of the MaiU, we learn of the existence of a 'Brahman-ritual' (brahmayajña, see the translation of MaiU I 1 above). The physical or external fires used in this rite are to be understood by the sacrificer as his own Ätman. Through the knowledge of the microcosmic and macrocosmic Ātman, the person 'who knows thus thinks upon the Ātman alone and sacrifices into the Ātman alone. ${ }^{63}$ However, in the same text the sacrificer is also said to be a 'renouncer' (samnnyāsin): 'He who knows thus is a renouncer, a yogin, a sacrificer into the self' ${ }^{64}$ and withdraws his senses from all external objects. But how can the sacrificer here be a yogin and, at the same time, a renouncer, who is generally not allowed to run any fire?

According to van Buitenen the second text passage is an interpolation of a redactor, which was added to the original MaiU from a later text of a similar name. In contrast to the "ritualistic" Ur-Upanișad, originally probably called Maitreya/

\footnotetext{
${ }^{62}$ For the correspondence of the three layers to the parts of the cosmos, cf. Oberlies (1988, p. 51). For the resulting quaternary $(3+1$, excluding the sacrificer / Knower of the Self) structure of the cosmos and its corollaries, see Norelius (2017, pp. 433-437).

${ }^{63}$ evamvid ătmann evābhidhyāyaty ātmann eva yajati $\mid$ MaiU VI 9. Cf. the tr. by van Buitenen (1962, p. 137).

${ }^{64}$ yo haivam veda samnyāsī yogì cătmayājī c[a] MaiU VI 10. Cf. the tr. by van Buitenen (1962, p. 139).
} 
Maitreȳ̄/Maitrī Upanișad, the inserted "Southern Maitrāyaṇ̂̄” is a Sāṃkhya-Yoga treatise "without Vedic relationships, which, had it been in ślokas, might have turned up as part of the Mokșadharma."65

If one accepts van Buitenen's elaborate reconstruction, ${ }^{66}$ the MaiU demonstrates that it was acceptable to compile texts which are contradictory in a certain way, especially if the merged texts share some characteristics. In the MaiU, for example, this is the teaching of the two Ātmans: while the original Upanișad speaks of the microcosmic/macrocosmic Ātman (viz. vital breath and sun), the Southern Maitrāyaṇ̄ deals with a physical/mental Âtman. ${ }^{67}$ Obviously, this technique of producing texts was accepted as a legitimate artistic device.

\section{The adhyātmayoga of the Kaṭha Upanișad}

Although the KU cannot be neatly divided into to a Northern or Southern text, the conceptual developments which took place before and during its composition prove to be very similar to those of the MaiU, for in the KU, too, ritual is combined with self-knowledge and yoga. According to Henk Bodewitz, the difficult verses KU $1.16-18^{68}$ (in all probability spoken by Death), refer to the different levels of interpretation of the ritual. Just like in other rituals, these are three: (1) the macrocosmic level related to the deities (adhidaivam), (2) the mesocosmic level related to ritual (adhiyajñam), and (3) the microcosmic level related to the body of the yajamāna (adhyātmam).

These are understood in the $\mathrm{KU}$ as three coordinated rituals performed simultaneously on the macro-, meso- and microcosmic level. ${ }^{69}$ The patron of the sacrifice, who belongs to the microcosm, must enter into a connection with these rituals forming a triad, i.e., he must identify them with each other and with himself. This concerns three specific entities in particular: the Brahman, the Srnikā and the 'praiseworthy' (ịdya) god. ${ }^{70}$

According to the usual logic of the sacrifice, the praiseworthy god must be the self, which is also called deva in 2.12 and 2.21. As the first, last, and supreme principle, knowledge of the self is the highest religious goal and as such it is also

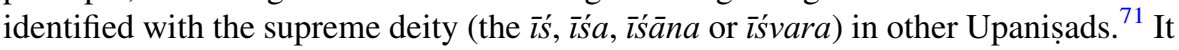
is thus more than likely that the praiseworthy god (deva $\bar{l} d y a)$ at this point of the

\footnotetext{
65 Van Buitenen (1962, p. 21).

66 His work was reviewed positively by Paul Hacker (1966). Cohen (2008, p. 256) finds it "unnecessarily complicated" and takes the older (the non-Southern text) to be an addition to the Southern Maitrāyaṇī; however, she does not go into this matter in more detail in this context.

67 See van Buitenen (1962, pp. 26-27).

68 For translations, see Olivelle (1998, pp. 377, 379) and Haas (2018, pp. 19-20).

69 This can be seen in the expression trikarmakrt which can only refer to 'someone who performs three rituals' and not a 'triple' ritual or the like.

70 For more details on the identification of these entities, see Bodewitz 1985.

71 See, e.g., BĀU IV 4.15 (ātman = deva = isśāna); V 6.1 (puruṣa = sarveśāna); KauU III 8 (ātman= lokapāla, lokādhipati, lokeśa); Māṇ̣̄ūkya Upanișad (MāU) 6 (ātman = sarveśvara); Muṇụaka Upaniṣad (MuU) III 1.2-3 (puruṣa = kartr, iśa).
} 
$\mathrm{KU}$, which is very close to the ritual, does not only designate the Ātman, but at the same time also the one god identical with it. $^{72}$

The most important manifestation of this god is the sun. In KU I 17 (for a translation, see above), a mysterious entity called brahmajajñ is associated with this deva. According to Bodewitz (1985, p. 23), "brahmajajñam refers to the verse brahmajajñanam [...], which accompanies the laying down of the gold plate, the rukma, which in my hypothesis is called srinka in this particular piling." In this verse, which can be found in various texts, bráhma jajñānám refers to the rising sun. $^{73}$

As has recently been shown by Johan-Per Norelius (2017), the connection and even identification of the self with the sun can be found in several other texts, too. Norelius observes how the anthropomorphic conception of the Purușa, who was envisioned as a little person with solar characteristics within man, in the course of time gradually gave way to the theory of a more abstract and transcendent being.

The fate of the post-Vedic puruṣa conception is characterized by a decline in favor of the atman-theory. In the Sāmkhya-influenced speculations of the epic the term [purușa] is still often used interchangeably with ätman to designate the soul, though its anthropomorphic traits are seldom referred to; yet a nonphilosophical text like the Sāvitrī story-which presumably draws on more popular beliefs-still describes the "thumb-sized" manikin that is extracted from Satyavant's body by the god of death, in a manner reminding one of the Vedic homunculus and its extraction from the body, like a reed from its sheath. $^{74}$

In the KU, this solar being is said to reside within the cave of the heart and must be realized with the help of 'knowledge' or 'recognition' (adhigama) which is produced by the so-called adhyātmayoga, i.e., the "yoga that focuses on the self., 75

\footnotetext{
72 As Bodewitz (1985, pp. 23-24) puts it: "The devah $\bar{l}$ dyah is the sun, the manifestation of brahman, the gold plate, the fire, the soul, the iśvara." In the KU, the Ātman is identified with the one god (iśäna etc.) or called "deity" (deva) in following places: 2.12 (tam durdarśam gūdham anupravistam guhāhitam gahvaresțham purānam [...] devam matvā [...]), 2.21 (kas tạ̣ madāmadam devam madanyo jñātum arhati), 4.5 (ya imam [...] veda ätmānam [...] ìsánam), 4.12-13 (añgușthamātrah puruṣo [...] iśāano bhütabhavyasya [...]), (5.8 [puruṣo (...) tad eva śukram tad brahma tad evāmṛtam ucyate]), 5.12 (eko vaśī sarvabhūtāintarātmā).

73 Among others, the verse can be found in the Taittirīya Saṃhitā (TS IV 2.8.8d): bráhma jajñānám prathamám purástād, ví sìmatáh surúco vená āvaḥ / sá budhníyā upamá asya viṣthāḥ, satáś ca yónim ásataś ca vívah // 'The Brahman born first in the east Vena has unveiled from the brightly shining boundary (= the horizon), its radiations from the depth, he has opened the womb of being and of nonbeing.' In the ŚB (VII 4.1.14) the verse is explained as follows: bráhma jajñānám prathamám purástād íti | asáu vấ ādityó bráhmáharahah purástāj jāyate [...]| “"The Brahman born first in the east ...”: Brahman is yonder sun; it is born day by day in the east.'

${ }^{74}$ Norelius (2017, p. 462).

75 adhyātmam is used in the older Upanișads only in the context of the three levels of interpretation of the sacrifice as an adverb meaning 'with reference to the self / the body'; see Rawson (1934, p. 94), n. 4. However, the wording here plays with another possible translation of the atman: adhyātma obviously means 'with reference to the self' not in the sense of the body but of the immortal essence. Cf. Rawson's translation (1934, pp. 92-93): "Here adhyātma-yoga may be rendered 'spiritual concentration' or, more specifically, "concentrated meditation upon the Self.",
} 
Now this wording must not be taken to simply refer to yoga in the sense of Epic Sāmkhya-Yoga or even the yoga of Patañjali. Rather, in the KU we see a transition in progress: the solar dwarf of the ritual's gnostic teachings is tacitly identified with the more abstract conception of the Sāmkhya-Yoga passages, where he is described as an all-pervading entity without any marks or attributes. What is important here is that the older conception of the soul as a homunculus within the body obviously persisted even when more abstract and sophisticated notions were already in existence, and as I will show below, popular or unsophisticated belief (with which yogins, mystics and philosophers of all kinds were certainly familiar) may have been very influential in another case of the $\mathrm{KU}$, too.

\section{Conclusions to the section "The Agnicayana and the Self"}

The evidence presented above shows different ways in which the Agnicayana was drawn upon in several Upanișads as part of a strategy to conceptualize their new teachings on the self within the framework of known Vedic categories. In the ChU (see above, "Śāṇ̣ilya's Doctrine in the Chāndogya Upaniṣad"), an Upaniṣadic teaching was related to a similar teaching associated with the Agnicayana by ascribing it to Sanndilya, one of the most famous mystic expounders of the ritual. In the TU (3b), an Agni is built verbally or mentally with five bodies or selves, the innermost of which is the blissful Ātman. The ŚU likens the body of a yogin to the threefold structure of the fire-altar (3c). In the older layers of the MaiU, we find a verbal or mental, inner ritual similar to that of the TU (3d). This ritual aims at "throwing up" the sacrificer to Brahman, which appears to be located above the three worlds. In the later parts of the texts, this sacrificer becomes a yogin, and the original teaching based on ritual is reinterpreted and continued in a new way.

Many of these connections have been recognized before. What I have tried to show is that they can indeed be very loose: there is no one pattern in which the ritual is reused, but rather, many. Also, the fact the ritual was, in practice, very different from self-knowledge or yoga shows that the former did not impose any restrictions on this reuse. Authors of several texts from different periods found it advisable to tie up their teachings with the famous Vedic ritual.

In view of this specific development, it can be assumed that also in the KU, the Agnicayana is taught essentially in the sense of the (re-)interpretation and reuse developed in the old and middle Upanișads. Although it is said that Death teaches Naciketas 'which bricks and how (they are to be laid)' (KU 1.15), the focus of the text is on that which makes the Agnicayana effective, namely the knowledge of its meaning or the realization of the mystical correspondences underlying it.

However, to the chagrin of scholars living some two millennia later, the authors did not stop at this. Especially in the 3rd, 5th and 6th Vallis there are also instructions which go beyond ritual, mere knowledge of the self and the renunciation of worldly evils. The first verses of this kind can be found in the 3rd Valli, which for the most part revolves around the parable of the carriage; in the 6th Valli the subject is dealt with again in a very similar form. In both sections there are references to practices that belong to yoga; in particular, the restraint of the senses is emphasized. The goal of these practices is characterized by a certain contradictoriness: on the one hand, the 
individual self is liberated from its individuality by yoga-after all, the one self common to all beings is to be recognized; on the other hand, as in the Nāciketacayana, there is mention of reaching a heavenly sphere.

The common intersection of the two paths to salvation is obvious: the individual self was the central object of speculation and cognition already in some parts of the ŚB and in the early Upaniṣads, which are still firmly anchored in the language and worldview of the ritual. This speculation was always also conducted with the aim of clarifying the relation between self and mortality, and the knowledge of the essence of the self was often understood as a means to its immortalization.

Whilst the practical relationship between ritual and knowledge is not always clear, it cannot be denied that the performance of physical ritual became less and less important for those who were intent on finding the true self. The techniques of yoga, which are explained in the KU only very elliptically and are not further elaborated, could be understood to be an answer to the question about the method for self-knowledge. The self, which is taught in the sacrificial mysticism of the Agnicayana, in the Upanișadic doctrine of knowledge, and finally also in yoga, has many faces, but in the end, it is one and the same. The abandonment of outer and material things, which already in the first Vallī dull or 'wear off the shine/sharpness of all senses' (sarvendriyānām jarayanti tejah, KU 1.26), finds its logical consequence in yoga, which serves to tame the senses.

But how could those who first heard the text in the same or similar form as we have it today harmonize the different aims of ritual, self-knowledge and yoga? Did they regard all of them as leading to the same goal? In the following, I want to show how the $\mathrm{KU}$ might have been understood by its first transmitters, redactors, and recipients by re-evaluating the various descriptions of the salvation goal(s) in the text.

\section{Heaven, Liberation and the World of Brahman}

\section{Salvation in the Kaṭha Upanișad}

Taking a closer look at how the salvation taught in $\mathrm{KU}$ is characterized, one can see that it is often described in very similar words. Most often it is designated as (postmortal) immortality (amrta) ${ }^{76}$ In different formulations this goal can be discovered throughout the whole text. ${ }^{77}$ It is also consistently said that by achieving the final goal one is freed from sorrow and pain $^{78}$ and experiences happiness, joy and

\footnotetext{
76 Cf. Collins (1992, p. 224): “The word normally translated 'immortality,' amrtam, in its earliest occurrences meant simply 'non-dying,' in the sense of continuing life; thus it was no paradox for Vedic hymns to aspire to the possession of amrtam as a 'full life' (sarvam āyuh) lasting one hundred years." Only in later times was this extended to the continuation of life after death. KU 1.17-18 and Naciketas's contrasting of the agelessness of the gods and a full life on this earth in 1.27-28 show that here the latter conception is in effect.

771.12 (na tatra tvam [= Death]); 1.13 (svargalokā amrtatvam bhajante); 1.18 (sa mrtyupāsáan puratah pranodya); 3.15 (mrtyumukhāt pramucyate); 4.1 (amrtatvam icchan); 4.2 (dhīrā amrtatvam viditvā); 5.8, 6.1 (tad eva śukram tad brahma tad evāmrtam ucyate) with reference to the Ātman and the aśvattha; 6.9 (ya etad vidur amrtās te bhavanti); 6.14, 6.15 (atha martyo 'mrto bhavati); 6.16 (amrtatvam eti); 6.18 (brahmaprāpto virajo 'bhūd vimrtyuh); 6.17 (tạ̣ vidyāc chukram amrtam) with reference to Puruṣa. In
} 
peace. $^{79}$ The overcoming of rebirth (and of redeath) is ubiquitous; ${ }^{80}$ however, the verb muc 'to lose, to be liberated,' which is important in this context, is not used in the 1st, 2nd and 4th Valliss ${ }^{81}$ and samsāra, the 'wandering about' in the cycle of existences, is only once mentioned in 3.7.

Other statements, too, are limited to certain sections of the text. The World of Heaven is explicitly mentioned only in the 1st Valli, while in the 3rd we find just the 'highest remote region' (parama parārdha), which presumably is identical with heaven, and the 'highest place of Viṣnu.' ${ }^{82}$ The World of Brahman can only be found in the inserted excursus about the syllable Om, in the equally late final verse of the 3rd Vallī, and in the 6th Vallī, where its position is difficult to ascertain. ${ }^{83}$ Brahman itself is not mentioned in the 1st, 2nd and 4th Vallīs. ${ }^{84}$

What conclusions can be drawn from this evidence? Most importantly, it can be observed that the overcoming of rebirth and death (either by means of the ritual or of yoga) is also associated with a "place" or "region" (loka, pada). This place is identified as (a kind of) heaven in 1.12, 1.18 and 3.9; in the last case, it is even the result of yogic practice. ${ }^{85}$ But can all of these places be regarded as one and the same? While the very existence of various words suggests the existence of disparate notions, in the following I will show that for the first recipients of the KU it was indeed possible to blend them together into a single conception.

\section{The Blending of Concepts}

The idea that being in the svarga represents an impermanent state is prominent in the Brāhmanas, which often deal with the possibility of avoiding redeath

\section{Footnote 77 continued}

the second Vallī, immortality is implicit: 2.6 (ayam loko nāsti para iti mānī punah punar vaśam āpadyate $\boldsymbol{m e}$ [= Death]); 2.18 (na jāyate mriyate vā vipaścin); 2.19 (nāyam hanti na hanyate).

78 1.12, 1.18 (śokātigo modate svargaloke); 2.12 (harșaśokau jahāti); 2.22, 4.4, 5.1, 6.6 (dhīro na śocati). The 3rd Vallī is dominated by the parable of the carriage, which does not mention sorrowlessness.

$791.12,1.18$ (śokātigo modate svargaloke); 1.17 (śāntim atyantam eti); 2.13 (sa modate modanīyam hi labdhvā); 5.12 (sukham śáśvatam); 5.14 (anirdeśyam paramai் sukham); 5.13 (śāntih śáśsatī). The word sukha 'happiness' is thus limited to the 5th Vallī.

${ }^{80} 1.17$ (tarati janmamrtyū); 2.6 (ayam loko nāsti para iti mān̄̄ punah punar vaśam āpadyate me); (2.18 [na jāyate mriyate vā vipaścin]); 3.8 (tat padam āpnoti yasmād bhūyo na jāyate).

813.15 (mrtyumukhāt pramucyate); 5.1 (vimuktaś ca vimucyate); 5.4 (dehinah / dehād vimucyamānasya); 6.8 (yam jñātvā mucyate jantur amṛtatvam ca gacchati); (6.14 [yadā sarve pramucyante kāmāh]).

821.12 (svarge loke na bhayam kiṃcana); 1.12, 1.18 (śokātigo modate svargaloke); 3.1 (guhām praviștau parame parärdhe); 3.9 (so 'dhvanah pāram āpnoti tad viṣnoh paramam padam).

83 2.17, 3.16 (brahmaloke mahīyate); 6.5 (chāyātapayor iva brahmaloke).

843.2 (akșaram brahma yat param); 5.8, 6.1 (tad eva śukram tad brahma tad evāmṛtam ucyate) with reference to the Ātman and the aśvattha; 6.14 (atra brahma samaśnute); 6.18 (brahmaprāpto virajo 'bhüd vimrtyuh).

85 Regarding the highest place of Viṣnu and its connection to the Agni(-Cayana), Oberlies (1988, pp. 39-40) remarks: "Es darf vermutet werden, daß der Yogin (vgl. KU 3.3-8) Viṣnus Stätte, deren Lokalisierung im höchsten Himmel eng mit dem Mythos der drei Schritte Viṣnus verbunden ist, auf Agni als vāhana erreicht. Dadurch werden-zumindest von den Redaktoren der KU-der Yogin und der Altar-Schichtende, der ja auch auf dem Nāciketa-Feuer svarga (= viṣnuloka) erreicht, in unmittelbare Nähe zueinander gerückt." 
(punarmrtyu). The usual case in later literature is, of course, that heaven is contrasted with final liberation - which is eternal-by the proponents of the latter. As mentioned above, to counteract their criticism the proponents of Vedic ritual often proclaimed that it indeed has the power to keep the sacrificer in heaven, i.e., to let him enjoy immortality forever. In the KU, which builds on the conceptions of the Brāhmanas, heaven is also looked upon as an endless world. ${ }^{86}$ It is even stated that whoever carries out the Nāciketacayana overcomes birth and death (tarati janmamrty $\bar{u}$, 1.17). How this is to be understood is difficult to determine; the evidence of the conception of the cycle of rebirth underlying the teaching of the $\mathrm{KU}$ is scattered throughout the text. In order to clarify how liberation is conceived of in the KU, in the following I will examine the few verses that give us some indications on the subject.

In 1.6, man is likened to grain:

KU $1.6^{87}$

Look ahead!- -like the previous ones-look back! — so will be the later ones.

A mortal man ripens like grain; like grain he is born again.

The conception in effect here probably is that of the old Upanișads: the imagery employed may refer to the idea that humans are first transferred from the upper regions to earth by means of raindrops, which here are symbolized by seeds of grain. Just like the seeds are 'sown' on the earth and then start to grow upright, so human beings come down to earth in the myriads of raindrops only to ripen again.

Verse 2.6 implies that this process is understood to happen again and again:

KU 2.6 (8) $^{8}$

What comes after death lies hidden from a careless fool, who is deluded by the delusion of wealth. Thinking 'This is the world; there is no other,' he falls into my power again and again.

However, to the greater part of the text the conception of Samsāra, one of the most important characteristics of which is endless and distressful repetitiveness, is alien or at least irrelevant.

The theory of karman, too, is only referenced in two verses:

\section{KU 5.6-7 $\mathbf{7}^{89}$}

Come, I'll tell you this secret and eternal formulation of truth (brahman); and what the self becomes, Gautama, when it encounters death. /6/ Some selves

\footnotetext{
${ }^{86} \mathrm{Cf}$. KU 1.14 (the Agni is anantalokāpti, it 'leads to the attainment of an endless world'), 1.17 (it leads to unending peace) and 3.2 (the Nāciketa ritual is identified with the akșara brahman). Cf. also Kena Upanișad (KeU) IV .9: 'When someone knows this (upaniṣad, scil. the teaching of 'correspondences' presented in the text) in this way, having warded off evil, he becomes firmly established in the endless heavenly world that cannot be overpowered.' (yo vā etām evam vedāpahatya pāpmānam anante svarge loke ’jyeye pratitișthati pratitișthati $\mid$ ).

87 anupaśya yathā pūrve pratipaśya tathāpare / sasyam iva martyah pacyate saysam ivājāyate punah /6/.

88 na sāmparāyah pratibhāti bālam pramādyantam vittamohena mūḍam / ayam loko nāsti para iti mānī punah punar vaśam āpadyate me /6/. Tr. by Olivelle (1998, p. 283), modified. For the translation of sāmparāya, see Haas (2018, pp. 138-143).

${ }^{89}$ hanta ta idam pravakșāmi guhyam brahma sanātanam / yathā ca maraṇam prāpya ātmā bhavati gautama /6/ yonim anye prapadyante śarīratvāya dehinah / sthāṇumanye 'nusamyanti yathākarma yathāśrutam /7/.
} 
(dehinah) enter a womb to be embodied, others pass into a stationary thingaccording to (their) deeds (karman), according to (their) knowledge (śruta). /7/

Similar to the early Upanișads, this explanation looks like a foreign addition to an otherwise naturalistic rebirth cosmology, ${ }^{90}$ and a full-fledged Samsāra should not be assumed in the KU only because of this passage.

Despite the fact that it is a loka, the final goal of the Upanișad-even if it is explicitly achieved via mukti or mokșa-is characterized as a release from ageing, dying and being born again. This wording may indicate that the goal of the ritual is very similar to the famous World of Brahman, which otherwise does not feature prominently in the text. ${ }^{91}$ If the cycle of rebirth in the KU is similar to that described in texts where the World of Brahman is the result of liberation, it is very likely that the salvation goal of the $\mathrm{KU}$ is conceptually similar to this world, even if it may not bear the same name. In the following, I will corroborate my thesis that the creators of the KU really did have the brahmaloka (or a world very similar to it) in mind when they set about to upgrade the goal of the Nāciketacayana (svarga) by discussing several passages where a similar "merger of worlds" or blending of concepts took place.

First of all, the KU itself offers some interesting insights on this topic at the beginning of the 3rd Vallī:

KU 3.1 $-2^{92}$

Knowers of Brahman, men with five fires, and with the three Agnis of Naciketas-they call these two "Shadow" and "Light," the two who have entered - the one into the cave of the heart, the other into the highest region beyond, both drinking the truth in the World of Rituals rightly performed. $.^{93} / 1 /$ May we master the fire-altar of Naciketas, a dike for those who have sacrificed; the imperishable, the highest Brahman, ${ }^{94}$ the farther shore for those who wish to cross the danger. /2/

Obviously, the world gained by ritual—svarga, or here: the sukrtasya loka-is also reached by someone who or something which 'has entered the cave' of the heart. This cave, as we know, is inhabited by the Ätman. As the other verses of the Upanișad make clear, the most important fact about the Ātman is that it can be known, and that this knowledge entails a salvific effect. Even though the import of these verses is by no means absolutely clear, there can be little doubt that they imply

\footnotetext{
${ }^{90}$ Cf. Bronkhorst (2007, pp. 112-126).

${ }^{91}$ Its mentions in 2.17 and 3.16, which are definitely late additions, do not concern the ritual.

92 rtam pibantau sukrtasya loke guhām praviștau parame parārdhe / chāyātapau brahmavido vadanti pañcāgnayo ye ca triṇāciketāh /1/ yah setur ìjānānām akșaram brahma yat param / abhayam titîrșatām pāram nāciketai் śakemahi $/ 2$.

93 The significance of chāya and ätapa is not clear, and I can only offer a somewhat bold interpretation. The two terms may refer to two types of Âtman, viz. the first one, which has entered the sun (ätapa, actually its 'blazing heat') in the highest heaven. The other one may not be a 'shadow' (chāyā), but a 'reflection' of the solar self within the cave of the heart.

${ }^{94}$ In these verses, the Agnicayana is itself identified with Brahman. Probably the cause - the ritual—was metonymically transferred to the effect-the Brahman; cf. Alsdorf (1950, p. 633). Alsdorf, however, thinks that both verses are interpolations of a later ritualist.
} 
that delving into the Âtman eventually leads to the sukrtasya loka, the alias of svarga.

The idea that knowledge (specifically about the self) leads to the attainment of a loka - usually, brahmaloka - can be found in numerous places. However, the loka gained by knowledge is sometimes even referred to as svarga in the older Upanișads. ${ }^{95}$ In a poem of the BĀU (IV 4.8-21), for instance, it is clearly said that someone who knows the self and is released (vimukta) ${ }^{96}$ goes to heaven (svarga):

\section{BĀU IV 4.8 ${ }^{97}$}

The fine path, extended and old, has touched me-I've discovered it! By it the wise men, the knowers of Brahman, go to the heavenly world (svarga loka), upwards from here, released.

Thus, self-knowledge may even lead to the attainment of heaven. More often, however, the goal is called brahmaloka. In the ChU, the 'dike' (which in KU 3.1-2 is the Agni) ${ }^{98}$ is identified with the Ātman and explained as being the border to the ever-bright World of Brahman:

ChU VIII 4.1-399

Now, this self is a dike, a divider, to keep these worlds from colliding with each other. Days and nights do not pass across this dike, and neither does old age, death, or sorrow, or even good or bad deeds. All evil things turn back from it, for this World of Brahman is free from evil things. [...] |1| Upon passing across this dike, therefore, one even passes from night into day, for, indeed, this World of Brahman is lit up once and for all. $|2|$

The World of Brahman described here is an area of existence, a world or a 'space' (loka) in which the individual can stay forever. As can be concluded from the descriptions of the self and its journeys, this usually implies a disembodied but individual existence, a conception that is also prevalent in the KU. In the KU, the idea that the individual dissolves in Brahman is nowhere expressed, the only exception being the verses 4.14-15, where it is stated that the self becomes like water poured into water. ${ }^{100}$ Apart from these two verses, however, even though the

\footnotetext{
95 Cf. ChU VIII 3.3, AiU III 4, KeU IV 9.

96 The release mentioned in the text in all likelihood is not from Samsāra, but from the more naturalistic cycle of rebirths.

97 aṇuḥ panthā vitatah purāṇo, mām sprșțo 'nuvitto mayaiva / tena dhīrā apiyanti brahmavidah̆, svargam lokam ita ürdhvam vimuktāh //.

98 In the Kāṭhaka Saṃitā (40.12: 147.1-2), the dike is Agni, too, cf. Oberlies (1988, p. 38).

99 atha ya ātmā sa setur dhṛtir eșām lokānām asambhedāya | naitam setum ahorātre tarato na jarā na mrtyur na śoko na sukrtam na duṣkrtam | sarve pāpmāno to nivartante | apahatapāpmā hy eșa brahmalokah $|1|[\ldots]$ tasmād vā etam setum tīrtvāpi naktam ahar evābhiniṣpadyate | sakṛd vibhāto hy evaișa brahmalokah |2|. Tr. by Olivelle (1998, p. 277), slightly modified.

100 In general, the overcoming of the redeath (in heaven or another loka) and the dissolution of the individual in a highest entity are clearly distinguished from each other; cf. Bodewitz (1996, pp. 596-597). Accordingly, Bodewitz (1985, p. 6) speculates about the meaning of Naciketas's question: "Perhaps we have to interpret [the third question] as referring to the exact nature of the escape from punarmrtyu (the obsession of the Brāhmaṇas) and from punarjanman (the Upanișadic ideal); i. e. Naciketas asks whether one eternally lives on after death (the old Vedic ideal) or loses one's identity through absorption into a
} 
Ātman of every human being is essentially the same, it usually (at least in expression) maintains its integrity. The ideology of the text is clear: if you know your immortal self, it will advance to an immortal sphere, just as it does according to the text passages from the $\mathrm{B} \overline{\mathrm{A}} \mathrm{U}$ and the $\mathrm{ChU}$ translated above.

Given the fact that the $\mathrm{ChU}$ and $\mathrm{KU}$ both seem to share the naturalistic concept of rebirth and describe their goals using very similar wording, I venture to draw the conclusiothat the goal of the Nāciketacayana, svarga, is conceptually-i.e., in the minds of the authors and their audience-identical with the brahmaloka of the ChU. Leaving aside the fact that some (in all probability later) verses of the KU do actually call the goal of self-knowledge brahmaloka, the identification of brahmaloka and svarga also in the older parts of the text is not as far-fetched as it may seem: already before the KU, both have been known to be the result of selfknowledge, and both have been located in or above the sun-lit sky. ${ }^{101}$

The passages in the KU and in other Upanisads show that svarga did not simply remain as the old goal of ritual but that it could actually be "upgraded" to become the result of self-knowledge. From this, it is not a big step to equate it with liberation from rebirth and even Saṃsāra, as was obviously done. Contrary to other texts, the $\mathrm{KU}$ does not even once make the effort to highlight the differences in the plethora of its methods and teachings. Just as the Ātman (including the great Ātman which is God) essentially is one and the same, so too the goal of the ritual and the gnostic teaching belonging to it may be regarded as one and the same.

\section{The Goal of Yoga}

But what about the goal of yoga? Yoga is often understood as a method which aims at gaining absolute isolation (kaivalya) by withdrawing the senses and reabsorbing them into the inner self. The goal may thus be said to be beyond all types of lokas, which are most often regarded as parts of Samsāra and are therefore to be abandoned.

However, several well-known narrative passages in the Mahābhārata (MBh) indicate that the goal of yoga was not only thought of as an abstract state of being, but was actually imagined in a very vivid way. ${ }^{102}$ In these passages, yoga is depicted as a method which can transfer the soul of a dying person into the sun or to the body of another being. An excellent example for this kind of yoga is the report

Footnote 100 continued

highest principle or deity (the Upanișadic view)." In Vedic literature, however, there are also some hints to an intermediate stage between an individual existence in heaven and the dissolution in the highest principle, see Bodewitz (1996, pp. 597-598).

101 As is widely known, since the late Vedic times the World of Brahman is often said to be the highest among seven worlds, whereas the svargaloka only occupies the third position. However, since vagueness is a characteristic of the loka concept both in the Vedic and Epic literature (see Gonda 1966, pp. 109-111) and the KU is definitely not a text of definitions, this "mixing-up" of worlds might not have bothered the authors at all.

102 See White (2009a, b), and Brockington (2003, pp. 18-19; 2010) for more details. For a critical review of White 2009b, see Mallinson 2013 as well as Nicholson 2010. 
of Drona, who ascended to heaven / the World of Brahman through the application of yoga:

MBh VII 165.39-42 $\mathbf{2}^{103}$

Having resorted to yoga, that great ascetic who had become a light advanced to heaven [...] When he was gone, we had the impression of two suns (concentrated) in a single point, for the sky was filled with lights. And he entered the moon, which was shining like the sun, and in a twinkling, the light disappeared. When Drona had gone to the World of Brahman, there were cries of joy among the enraptured inhabitants of heaven [...] only we, five human beings, have seen how the great one who engaged in yoga went to the highest goal.

Elsewhere in the Epic, Bhūriśravas, an archer fighting on the side of the Kauravas, engages in an apparently meditative practice in order to enter the World of Brahman:

MBh VII 118.17c-18 184 $^{104}$

Desiring to go to the World of Brahman, he offered his vital breaths into the vital breaths, focused his gaze on the sun and his calm mind on water, ${ }^{105}$ and contemplating the great secret (upanișad) the sage became engaged in yoga.

Now it may rightfully be questioned whether these and other descriptions of the MBh can serve to explain the actual practice of yoga at all: in the end, the stories of the $\mathrm{MBh}$ are fictitious, even fantastic, and may just dramatize what was, in reality, a quite inner experience. ${ }^{106}$ Furthermore, there are various kinds of yoga methods: it is not entirely clear whether the practice of Droṇa and Bhūriśravas was the same as the yoga of the KU or the Mokșadharmaparvan. It even appears that the word yogayukta 'engaged in yoga' and the phrase yogam āsthāya 'having resorted to

$\overline{103}[. .$.$] yogam āsthāya jyotirbhūto mahātapāh / divam ākrāmad [...] /39/ dvau sūryāv iti no buddhir āsīt$ tasmims tathā gate / ekāgram iva cāsīd dhi jyotirbhih pūritam nabhah / samapadyata cārkābhe bhāradvājaniśākare 140/ nimeșamātreṇa ca taj jyotir antaradhīyata / āsīt kilakilāśabdah prahrșțānām divaukasām / brahmalokam gate droṇe [...] /41/ vayam eva tadādrākșma pañca mānușayonayah / yogayuktạn mahātmānam gacchantam paramām gatim /42/. For another translation, see White (2009a, p. 66, b, p. 69).

104 yiyāsur brahmalokāya, prāṇān prāṇeșv athājuhot // sūrye cakșuḥ samādhāya, prasannam salile manah / dhyāyan mahopaniṣadam yogayukto 'bhavan munih //. For a very different translation, see White (2009b, p. 69).

105 It is not clear what role salila 'water, flood, surge' plays in this context. Usually, salila refers to agitated water. However, several manuscripts used in the critical edition also read prasanne or prasannasalile 'on calm water' $\left(\mathrm{K}_{5}, \mathrm{D}_{2}, \mathrm{D}_{3}, \mathrm{D}_{6}, \mathrm{M}_{3}, \mathrm{M}_{4}\right.$ prasanne; $\mathrm{K}_{2}, \mathrm{Dn}_{1}, \mathrm{D}_{5}$ prasanna-). Since probably no real body of water is meant, the salila must be imaginary, as the mention of manas 'mind' suggests (the sun, on the other hand, apparently is the real one, as Bhūriśravas can set his eye on it). As Kenji Takahashi pointed out to me (personal communication), this could mean that by contemplating something that is clear and calm, one can make the mind clear and calm. The text of the critical edition, however, implies that the mind is already calm when contemplating the salila, which-despite the more general meaning of the word-must obviously be a calm one in all readings.

106 Thus, with regard to the passage translated above, Brockington (1998, p. 310) remarks that "it has been homologated with accounts of yogic experience in terms of incomparable radiance." Cf. also Brockington (2003, pp. 18-19). 
yoga' in many cases simply refers to the equanimity expected of a brave warrior in the face of death. ${ }^{107}$

Nevertheless, it is rather striking how the destiny of dying warriors-entering heaven or becoming one with the sun-comes close to the moksa of yogins (who are not warriors), which in the $\mathrm{MBh}$ is sometimes described with similar imagery. ${ }^{108}$ As has been noted by Brockington (2010, p. 23), this imagery partly goes back to the older Upanișadic worldview as described above. Considering the conceptualization of the salvation goal of the Nāciketacayana in the KU, it might be possible to go even further. In my view, the similarities between the world 'behind the sun' (párenādityám, TB III 11.7.4) which is gained by ritual and the radiant brahmaloka of the early Upanișads and the Epic yogins are great enough to conclude that the creators of the KU could take them to refer to one and the same sphere. While the imagery of light and radiance is certainly of great importance in the context of yoga, the very concrete descriptions given in the Upanișads ${ }^{109}$ suggest that it was not (only) an inner vision, but a certain conception of the cosmos which was responsible for the vivid accounts of the Epic.

The KU is primarily concerned with the self and not with heaven or liberation, and its notions of yoga and yogic concepts are comparatively abstract and theoretical. However, as can be seen from other sources, both the authors and the audience had the possibility to actually imagine their practice in a very vivid (and definitely very appealing) way. Thus, whilst some certainly would have distinguished between the goals of ritual, self-knowledge and yoga, others could easily inter-relate them due to their similar imagery and could even consider them as identical.

\section{Conclusions to the section "Heaven, Liberation and the World of Brahman"}

As has been shown above, the different salvation concepts are much closer than they initially appear. If one assumes that the KU was compiled by intelligent authors and redactors, and that the heterogeneity of its teachings is not merely a by-product of tradition, the juxtaposition of the salvation goals represents a highly interesting event in the religious history of South Asia. Not only does the KU belong among the earliest texts teaching the method of Sāmkhya-Yoga, but it actually connects the method with the (late) Vedic soteriology, which aims at securing for the patron of the sacrifice a life after death in heaven or behind the sun.

What remains open, however, is what role the Nāciketacayana played in the religious practice of those who devised the text. Since the powers of knowledge and also of renunciation are clearly in the foreground, it is highly probable that these methods were not only understood as a supplement of the ritual, but that they-at least in practice-actually replaced it. That these two paths are not explicitly harmonized in the text does not show that their different origins were not

\footnotetext{
107 See Brockington (2010, pp. 30-31).

108 Brockington (2010, pp. 28-29). A good example can be found in MBh XII 193.17-19; for an annotated translation, see Takahashi (2019, p. 442).

109 Cf., for example, Frauwallner (1926, pp. 6-9).
} 
recognized; rather, it may have been intentionally 'swept under the carpet' to present the connection of both traditions as self-evident and natural.

In view of the fact that the $\mathrm{KU}$ at no point gives any hint to its being antiritualistic in terms of ideology, and nowhere indicates that rituals are to be given up, it cannot be said to be an anti-ritualistic text. ${ }^{110}$ The creators of the text were conscious of the symbolism of the Agnicayana and its attached importance, and nowhere indicate that it is a bad practice which leads to undesirable results; rather, they even endeavor to link it with certain concepts of the ritual in order to create a framework for its new teaching. Further, the fact that Naciketas in both versions explicitly asks for a ritual that is named after him indicates at least prima facie that the literary figure of Naciketas was not employed to criticize the effectiveness of ritual.

Being deeply rooted in the early Upanișadic worldview, the KU tries to integrate a variety of concepts by avoiding any mention of differences between those it joins under its umbrella. The only difference between the goal of ritual and that of selfknowledge/yoga may be that knowledge of the Ātman/Brahman not only leads to immortality, but even to supreme bliss. Johnston (1939, p. 124) points out that

[t]he argument of the first adhyāya [is] that svarga, the reward of carrying out the Vedic ceremonies, is not the final goal, but merely a superior stage from which the supreme bliss [änanda] is absent. The happiness of heaven, as [KU 1.]12 says, consists in freedom from fear, particularly the fear of old age and death, and in release from hunger, thirst and grief.

Like many others, Johnston assumes a single dichotomy in the text: on the one hand, there is the ritual which in essence is to be connected with pleasures; ${ }^{111}$ on the other hand, we have the way of knowledge (and later, yoga) leading to supreme bliss. This, however, is a simplification which cannot be proven by the text: if the Nāciketacayana would have procured for Naciketas the pleasures of this world, it would not make sense to dissuade him from his third question by offering the very enjoyments he just obtained (1.23-25). If, on the other hand, the ritual only and primarily leads to the existence in an immortal sphere after death (as apparently is the case in the description of the KU), Death's offerings are much more reasonable.

$\mathrm{KU} 1.28$ makes clear that transient pleasures are worthless for somebody who, like Naciketas, has attained (upa+i) the freedom of old age which the gods enjoy in heaven (1.8). Therefore, he attempts to bind Naciketas, who will only be immortal after death, to this-worldly enjoyments. He does so in order to prevent him from

\footnotetext{
110 The term kratu (in akratu), which is used in 2.11 and 2.20 is often taken to refer to 'ritual,' can also mean 'desire,' and is probably used in this meaning also in the KU; cf. also Oberlies (1996, p. 152), n. 157. Both verses, which cannot be discussed here, therefore refer to the abandonment or absence of desires and pleasures. As the first two Vallis make clear, this (and not the devaluation of ritual) is one of the main themes of the text. Oberlies $(1988$, p. 37, n. 13) notes that ritual generally is not devaluated in the Upanișads of the Yajur Veda (unlike, for instance, in the PU and MuU belonging to the Atharva Veda).

111 A view most clearly expressed by Geldner (1901, p. 154, n. 1): "Im zweiten Vara erbittet Naciketas die Mitteilung des zum Himmel führenden Feuers (13). Er steht hier also noch ganz auf dem Boden des Karmakâṇ̣a, dessen höchsten Ziele die Himmelsgenüsse sind.” The view is also shared by Charpentier (1928, p. 206).
} 
pursuing a much more effective knowledge even in this life: the various instances where the result of self-knowledge or yoga is described in the present tense obviously imply a salvific practice and goal even in this current life. This, again, may have been a reaction to other forms of spirituality; as is well known, in Buddhism, reaching Nirvāṇa immediately leads to an experience of happiness and bliss. Although it would indeed make sense that the authors of the text also viewed the final result of their way of knowledge-which is characterized both by immortality and bliss_-as superior, I would rather argue that their main aim was to propagate their new method which is based on knowledge.

Almost a century ago Barend Faddegon (1923) argued that it may be unwise to demand great consistency from the KU. He pointed out that the text is highly honored in India and that it is a shortcoming of "Western" interpreters that they are unable to appreciate its approach. For him, the KU basically is a fairytale, and its naive attempt to connect ritual and mysticism should not be criticized too severely. He concludes his defense of the text thus: 'In a word, whoever wants to appreciate the poets of the Upanișads, must be able to be for a while-simple in spirit., ${ }^{112}$

Without insinuating mere stupidity on the part of the authors, I think that Faddegon's statement contains a grain of truth. In the eyes of the authors and their audience, who may not have been as inclined to philosophical scrutiny as later commentators and modern researchers, the differences between svarga, brahmaloka and liberation from rebirth may in fact have been secondary in terms of the concepts they represent. This is not to say that they were incapable of distinguishing between ritual, self-knowledge and yoga, or between heaven, the realm of Brahman and liberation. What counts is that it was at least possible that these could, in one way or another, be connected with each other. The differences may have been far less important than the fact that a new doctrine or technique could somehow be related to an existing Brahmin narrative. To them, the KU taught a new way to achieve a goal which is presented as having been part of the Vedic tradition since the days of yore, a secret knowledge which is actually as effective as the great Agnicayana.

The underlying assumption here is, of course, that there can be only one highest goal which - thanks to Naciketas's curiosity-must no longer be reached by carrying out any physical ritual. While the ritual, in a very elaborate manner created a new body for a human being after death, the realization of the immortal self not only leads to the same goal, but alleviates the agonies of daily existence already in this life. The fact that this self does not need to be constructed, but has already been within and actually only needs to be discovered with the help of the Upanișad (and a Brahmin teaching it), definitely suggested that this was the superior means to immortality and happiness. In addition, this method was much cheaper-as Frederick M. Smith (1988) has shown, the ever-growing costs in the financing of Śrauta-rituals eventually affected ritual itself and, over the course of time, even led to its nearly complete disappearance.

Since Naciketas is a fictitious character designed to act in the way the authors wanted him to, it is advisable to interpret his actions against the background of their

\footnotetext{
$\overline{112}$ Tr. of Faddegon (1923, p. 18): "In één woord, wie de dichters der Upaniṣads wil kunnen waardeeren, moet voor een wijl kunnen zijn—eenvoudig van geest.".
} 
thoughts and worldview. His third wish may thus be simply understood as a manifestation of the general maxim of Upanișadic literature, namely that knowledge is power. ${ }^{113}$ Naciketas, being aware that he-as opposed to most others-is now immortal and assuming that there is more on the subject, wants to know everything about it. ${ }^{114}$ This does not imply that the object of his enquiry is in any way opposed to the ritual he has just been taught. As Naciketas points out, Death's attempts at distracting him are rather futile, for he has just been made immortal anyway. ${ }^{115}$ The reason for his asking is not to be found in any lack of the Nāciketacayana. Rather, it must be understood as a clever device of the story-maker(s), who in this way could show that the knowledge about the immortal self actually comes from Death himself. For the unprejudiced reader, the fact that (as in the TB) the third wish does not supersede the second need not be a surprise.

\section{Concluding Remarks}

As I have endeavored to show, the KU represents an attempt to homologize and syncretize various religious terminologies and approaches rather than to devalue or overcome an outdated salvation goal. This is accomplished by redefining several crucial concepts which would otherwise be in stark contrast:

1. The Agnicayana, a powerful ritual that was known to effectuate infinite immortality after death, is intimately linked to a method of self-knowledge; it is even said to be the self itself. While formerly this self was constructed in the ritual, it now can be recognized by those who have the right knowledge.

2. The goal of the ritual, svarga, is (re-)defined as leading to freedom from rebirth and redeath and as such corresponds to the salvation goal (often called brahmaloka) which is presented in other texts as the result of a gnostic method that is otherwise often opposed to ritual activity.

3. The techniques of yoga are integrated into the text as a means to accomplish selfknowledge and in practice replaced the expensive ritual.

The lack of consistency in this piling of concepts indicates that it was method which was most important. By evoking the story of pious Naciketas, who since the TB has been known for scolding his father for not performing his ritual properly, all teachings of the text are brought into the Vedic fold. The fact that ritual eventually becomes unimportant in practice was of little interest to the authors, who primarily tried to show that their teaching complies with Vedic tradition. It is precisely the absence of any problematization (which would otherwise be expected in such a text) that proves what the authors tried to represent as self-evident and given.

\footnotetext{
113 Cf. Edgerton (1929).

114 Remember that in 1.14 Death mysteriously hinted at the Agni in the heart, the place where Naciketas (and the audience of the text) must have expected the Ātman.

115 In fact, the text only says that if someone 'has obtained the agelessness of the immortals' (ajīryatäm amrtānām upetya), there is no sense in wishing for a long life (1.28). However, I presume that Naciketas is implying himself and that he may even be making fun of Death's offerings.
} 
The framework narrative clearly demonstrates that it was Brahmins who were responsible for this project. Their reasons for creating the KU can only be speculated upon. Obviously, the practitioner of the KU is not in need of a Brahmin priest in order to gain salvation. This, however, did not necessarily remove the Brahmins from their status, because-whether as sacrificial priests or yoga teachers-the assimilation of non-Vedic elements confirmed their necessity as knowledge mediators. ${ }^{116}$

\section{Primary Literature and Abbreviations}

I have used Olivelle's (1998) edition of the Upanișads, Oberlies's (1995/96/98) edition of the ŚU, van Buitenen's (1962) edition of the MaiU, Weber's editions of the SB (1855) and TS (1871), Dumont's edition of the TB (1948-1969, published in several parts in the Proceedings of the American Philosophical Society), and the Pune edition of the MBh (1927-1966).

$\begin{array}{ll}\text { AiU } & \text { Aitareya Upanișad } \\ \text { BĀU } & \text { Bṛhad Āraṇyaka-Upanișad } \\ \text { ChU } & \text { Chāndogya Upanișad } \\ \text { JIP } & \text { Journal of Indian Philosophy } \\ \text { MāU } & \text { Māṇụūkya Upanișad } \\ \text { MaiU } & \text { Maitrāyaṇīya Upaniṣad } \\ \text { MuU } & \text { Muṇụaka Upaniṣad } \\ \text { MBh } & \text { Mahābhārata } \\ \text { KauU } & \text { Kaușītaki Upaniṣad } \\ \text { KeU } & \text { Kena Upanișad } \\ \text { KU } & \text { Kațha Upanișad } \\ \text { PU } & \text { Praśna Upanișad } \\ \text { SBB } & \text { Śatapatha Brāhmaṇa } \\ \text { SBE } & \text { Sacred Books of the East } \\ \text { ŚU } & \text { Śvetāśvatara Upanișad } \\ \text { TB } & \text { Taittirīya Brāhmaṇa } \\ \text { tr. } & \text { translation } \\ \text { TS } & \text { Taittirīya Saṃhitā } \\ \text { TU } & \text { Taittirīya Upanișad } \\ \text { WZKS } & \text { Wiener Zeitschrift für die Kunde Südasiens } \\ \text { ZDMG } & \text { Zeitschrift der Deutschen Morgenländischen Gesellschaft }\end{array}$

\footnotetext{
116 Cf. Rawson (1934, p. 62): "To some extent [...] the Katha may be regarded as a piece of Brahmin propaganda. It represents the supreme knowledge of the Atman as having been divinely revealed to a Brahmin, whereas the older Upanișads represent this knowledge as first attained by Kṣatriyas and communicated by them to Brahmins." Furthermore, the story also shows what status the Brahmins wanted to confer on themselves.
} 
Acknowledgements Open access funding provided by University of Vienna.

Open Access This article is distributed under the terms of the Creative Commons Attribution 4.0 International License (http://creativecommons.org/licenses/by/4.0/), which permits unrestricted use, dis tribution, and reproduction in any medium, provided you give appropriate credit to the original author(s) and the source, provide a link to the Creative Commons license, and indicate if changes were made.

\section{References}

Alsdorf, L. (1950). Contributions to the textual criticism of the Kathopanișad. ZDMG, 100, 621-637.

Beall, E. F. (1986). Syntactical Ambiguity at Taittirīya Upanisad 2.1. Indo-Iranian Journal, 29(2), 97102. https://doi.org/10.1163/000000086790082091.

Bodewitz, H. W. (1985). Yama's second boon in the Katha Upanișad. WZKS, 29(1985), 5-26.

Bodewitz, H. W. (1996). The Hindu doctrine of transmigration: Its origin and background. Indologica Taurinensia, 23-24, 583-605.

Bodewitz, H. W. (2002). The dark and deep underworld in the veda. Journal of the American Oriental Society, 122(2), 213-223.

Böhtlingk, O. (1890). Drei kritisch gesichtete und übersetzte Upanishad mit erklärenden Anmerkungen. Berichte über die Verhandlungen der Sächsischen Akademie der Wissenschaft zu Leipzig, 42 (pp. 127-197). Leipzig: S. Hirzel.

Böhtlingk, O. (1891). Zu den von mir bearbeiteten Upanishaden. Berichte über die Verhandlungen der Sächsischen Akademie der Wissenschaft zu Leipzig, 43 (pp. 70-90). Leipzig: S. Hirzel.

Brockington, J. (1998). The Sanskrit Epics. Brill.

Brockington, J. (2003). Yoga in the Mahābhārata. In I. Whicher \& D. Carpenter (Eds.) Yoga. The Indian Tradition (pp. 13-24). Routledge.

Brockington, J. (2010). sūrya ivāparaḥ: Exemplary deaths in the Mahābhārata. In A. Bigger, R. Krajnc, A. Mertens, M. Schüpbach, \& H. W. Wessler (Eds.), Release from life-Release in life Indian perspectives on individual liberation (pp. 21-34). Pieterlen: Peter Lang.

Bronkhorst, J. (2007). Greater Magadha. Studies in the culture of early India. Leiden: Brill.

Charpentier, J. (1928/1929). Kâthaka Upanișad. Translated with an Introduction and Notes. The Indian Antiquary, 57: 201-207 [cont'd on] 221-229/58: 1-5.

Cohen, S. (2008). Text and authority in the older Upanișads. Leiden: Brill.

Collins, S. (1992). Nirvāna, time, and narrative. History of Religions, 31(3), 215-246.

Converse, H. S. (1974). The Agnicayana rite: Indigenous origin? History of Religions, 14(2), 81-95.

Deussen, P. (1894). Allgemeine Geschichte der Philosophie. Mit besonderer Berücksichtigung der Religionen. Erster Band. [Erste Abteilung: Allgemeine Einleitung und Philosophie des Veda bis auf die Upanishad's]. Leipzig: F. A. Brockhaus.

Deussen, P. (1921). Sechzig Upanishad's des Veda. Aus dem Sanskrit übersetzt und mit Einleitungen und Anmerkungen versehen. Dritte Auflage. Leipzig: F. A. Brockhaus.

DeVries, L. (1987). The father, the son and the Ghoulish host: A fairy tale in early Sanskrit? Asian Folklore Studies, 46(2), 227-256. https://doi.org/10.2307/1178586.

Dumont, P.-E. (1951). The special kinds of Agnicayana (or special methods of building the fire-altar) according to the Kațhas in the Taittirīya-Brāhmana. The tenth, eleventh, and twelfth Prapāthakas of the third Kānḍa of the Taittirīya-Brāhmana with translation. Proceedings of the American Philosophical Society, 95(6), 628-675.

Edgerton, F. (1929). The Upanisads: What do they seek, and why? Journal of the American Oriental Society, 49, 97-121. https://doi.org/10.2307/592977.

Eggeling, J. (Tr.) (1897). The Satapatha-Brâhmana according to the text of the Mâdhyandina school. Part IV: Books VIII, IX, and X [SBE 43]. Oxford: Clarendon Press.

Faddegon, B. (1923). De interpretatie der Kāṭhaka-Upanișad. In Mededeelingen der Koninklijke Akademie van Wetenschappen, vol 55, Series A (1-18). Amsterdam.

Frauwallner, E. (1926). Untersuchungen zu den älteren Upanișaden. Zeitschrift für Indologie und Iranistik, 4, 2-45.

Freedman, Y. (2012). Altar of words: Text and ritual in Taittirīya Upaniṣad 2. Numen, 59(4), 322-343. https://doi.org/10.1163/156852712X641778. 
Freschi, E. (Ed.) (2015). The reuse of texts in Indian philosophy. Special Issues of the JIP, 43(2-3 and 45), 85-108, 335-388.

Freschi, E., \& Maas, Ph A (Eds.). (2017). Adaptive reuse. Aspects of creativity in South Asian cultural history. Wiesbaden: Harrassowitz Verlag.

Friš, O. (1955). Two readings of the Kaṭhopanișad. Archiv Orientální, 23, 6-9.

Geldner, K. F. (1901). Übersetzungen aus dem RV. In R. Pischel \& K. F. Geldner (Eds.), Vedische Studien 3 (pp. 147-183). Stuttgart: W. Kohlhammer.

Gonda, J. (1966). Loka. World and heaven in the veda. Amsterdam: N.V. Noord-Hollandsche Uitgevers Maatschappij.

Gotō T. (1996). Zur Lehre Śāndililyas. In N. Balbir \& G.-J. Pinault (Eds.) [avec la collaboration de Jean Fezas], Langue, style et structure dans le monde indien. Centenaire de Louis Renou (pp. 71-88). Paris: Éditions Champion.

Grinshpon, Y. (2003). Crisis and knowledge. New York: Oxford University Press.

Haas, D. (2018). Vom Feueraltar zum Yoga. Kohärenz und Konzept der Kața-Upaniṣad. Master's thesis. Vienna: University of Vienna.

Hacker, P. (1966). Review of van Buitenen 1962. ZDMG, 116(1), 214-215.

Helfer, J. S. (1968). The initiatory structure of the Kațopanișad. History of Religions, 7(4), 348-367.

Hill, P. (2001). Fate, predestination and human action in the Mahābhārata: A study in the history of ideas. New Delhi: Munshiram Manoharlal.

Hillebrandt, A. (1897). Ritual-Litteratur. Vedische Opfer und Zauber. Strassburg: Trübner.

Hillebrandt, A. (1914). Textkritische Bemerkungen zur Kāthaka und Praśna-Upanișad. ZDMG, 68, 579_ 582.

Johnston, E. H. (1939). On some difficulties of the Katha Upanisad. In S. M. Katre \& P. K. Gode (Eds.), $A$ volume of eastern and Indian studies (pp. 122-127). Bombay: Karnatak Publishing House.

Lipner, J. J. (1978). An analysis of Katha 6.4 and 5, with some observations on Upanishadic method. JIP, 5(3), 243-253. https://doi.org/10.1007/BF00161266.

Mallinson, J. (2013). The Yogīs' latest trick [review of White 2009b]. Journal of the Royal Asiatic Society of Great Britain \& Ireland, 24(1), 165-180.

Müller, F. M. (Tr.). (1884). The Upanișads. Part II. [SBE 15]. Oxford: Clarendon Press.

Nicholson, A. J. (2010). Review of White 2009b. Journal of the American Oriental Society, 130(2), 277279.

Norelius, P.-J. (2017). Mahān purușaḥ: The Macranthropic soul in Brāhmaṇas and Upaniṣads. JIP, 45, 403-472. https://doi.org/10.1007/s10781-017-9316-4.

Oberlies, Th. (1988). Die Śvetāśvatara-Upanișad: Eine Studie ihrer Gotteslehre. (Studien zu den „mittleren” Upanișads I). WZKS, 32, 35-62.

Oberlies, Th. (1995). Die Śvetāśvatara-Upanișad: Einleitung-Edition und Übersetzung von Adhyāya I. (Studien zu den ,mittleren” Upanișads II-1. Teil). WZKS, 39, 61-102.

Oberlies, Th. (1996). Die Śvetāśvatara-Upanișad: Edition und Übersetzung von Adhyāya II-III (Studien zu den „mittleren” Upanișads II-2. Teil). WZKS, 40, 123-160.

Oberlies, Th. (1998). Die Śvetāśvatara-Upanișad: Edition und Übersetzung von Adhyāya IV-VI (Studien zu den ,mittleren” Upanișads II-3. Teil). WZKS, 42, 77-138.

Olivelle, P. (Tr.) (1998). The early Upanișads. Annotated text and translation. Oxford: Oxford University Press.

Pune edition of the MBh (1927-1966). In V. S. Sukthankar et al. (Eds.), Mahābhārata (Vol. 19). Poona: Bhandarkar Oriental Research Institute.

Rawson, J. N. (1934). The Kațha Upanișad. New York: Oxford University Press.

Smith, F. M. (1988). Financing the vedic ritual: The Mūlyādhyāyapariśișța of Kātyāyana. WZKS, 32, 6375.

Smith, C. Ch. (2016). The Kațhopanișad and the deconstruction of the fire-altar. In A. M. Byrd, J. DeLisi, \& M. Wenthe (Eds.), Tavet Tat Satyam [studies in honor of Jared S. Klein on the occasion of his seventieth birthday] (pp. 283-293). Ann Arbor/New York: Beech Stave Press.

Staal, F. (Ed.). (1983). Agni. The vedic ritual of the fire altar (Vol. 1-2). Berkeley: Asian Humanities Press.

Takahashi, K. (2019). The Manas and the Manovahā channel in the Vārșneyādhyātma of the Mahābhārata: A critical reading of Mahābhārata 12.207.16-2. JIP, 47, 421-452. https://doi.org/10. 1007/s10781-019-09387-0.

van Buitenen, J. A. B. (1962). The Maitrāyaṇīya Upaniṣad. 'S-Gravenhage: Mouton \& Co. 
Velankar, H. D. (1968). The Rgvedic Origin of the Story of Naciketas (RV 10.135). In Mélanges d'indianisme. À la mémoire de Louis Renou (pp. 763-772). Paris: de Boccard.

Wadhwani, Y. K. (1973). Implication of the Vedic Term Naciketas. Vishveshvaranand Indological Journal, 11, 19-23.

Weber, A. (Ed.). (1855). The Çatapatha-Brâhmaña in the Mâdhyandina-Çâkhâ with extracts from the commentaries of Sâyaṇa, Harisvâmin and Dvivedaganga. Berlin/London: Dümmler/Williams and Norgate.

Weber, A. (1871). Die Taittirîya-Saṃhitâ. In A. Weber et al. (Hrsgg.), Indische Studien. Beiträge für die Kunde des indischen Alterthums. Band 11. Leipzig: F. A. Brockhaus.

Weber, A. (1873). Zur Kenntniss des vedischen Opferrituals. (Fortsetzung). In A. Weber et al. (Hrsgg.), Indische Studien. Beiträge für die Kunde des indischen Alterthums. Band 13 (pp. 217-292). Leipzig: F. A. Brockhaus.

Weller, F. (1953). Versuch einer Kritik der Kațhopanișad. Berlin: Akademie-Verlag.

White, D. G. (1986). "Dakkhina” and “Agnicayana”: An extended application of Paul Mus's typology. History of Religions, 26(2), 188-213.

White, D. G. (2009a). Yogic rays: The self-externalization of the Yogi in ritual, narrative and philosophy. Paragrana, 18(1), 64-77.

White, D. G. (2009b). Sinister Yogis. Chicago: The University of Chicago Press.

Whitney, W. D. (1890). Translation of the Kațha-Upanishad. Transactions of the American Philological Association, 21, 88-112.

Publisher's Note Springer Nature remains neutral with regard to jurisdictional claims in published maps and institutional affiliations. 